\title{
La liberación de cautivos en la frontera de Granada (siglos XIII-XV)
}

\author{
The Freeing of Captives on the Frontier of Granada \\ (13th-15th Centuries)
}

\author{
José Enrique López de Coca CASTAÑer \\ Universidad de Málaga \\ jelopezd@uma.es
}

\begin{abstract}
RESUMEN
Castilla y Granada reconocían el derecho de los cautivos a buscar la salvación en la huída. Algunas fugas eran tan increíbles que se explicaban por la ayuda divina. Los rescates se pagaban con dinero procedente de legados testamentarios, limosnas y la ayuda oficial. Las rentas de bienes hábices garantizaban el pago de muchos rescates en el lado granadino. A veces los cautivos volvían a casa para reunir el dinero de su rescate, dejando a un miembro de su familia como rehén. Por razones religiosas, los moros preferían canjear cautivos en vez de rescatarlos. Los alfaqueques ponían en contacto a la familia del cautivo con el dueño de éste y procuraban que ambas partes llegaran a un acuerdo. Se esperaba de ellos que fuesen honestos, pero algunos aprovechaban su situación privilegiada para comerciar o espiar. Mujeres, niños y adolescentes recurrían a la apostasía para mejorar sus condiciones de vida. Pero esta opción era más traumática para los cristianos que para los musulmanes
\end{abstract}

Palabras clave: Cautivos, Alfaqueques, Apostasía, Castilla, Granada, Siglos XIII-XV.

\begin{abstract}
Castile and Granada recognized the right of captives to seek salvation by fleeing. Some escapes were so unbelievable that they could only be explained by divine intercession. The ransoms were paid with money from official assistance, testamentary bequests and alms. The rents of the waqf guaranteed the payment of many ransoms on the Granadan side. Sometimes captives went back home to get the money to pay for their ransoms, leaving members of their families as hostages. Religious reasons justify the Moors' preference for exchange of captives rather than rescuing them. The ransomers put the captive's family in touch with his master and they tried to help both sides reach an agreement. They were expected to be honest, but some took advantage of their privileged situations to trade or to spy. Women, children and the young apostatized to improve their living conditions, although this option was more traumatic for Christians than for Muslims.
\end{abstract}

Key words: Captives, Alfaqueques, Apostasy, Castile, Granada, XIIIth-XVth Centuries.

Sumario: 1.La fuga. 1.1. Reconocimiento del derecho a escapar. 1.2. La intervención sobrenatural. 1.3. Las prisiones de los cautivos. 2. La redención de cautivos. 2.1. Financiación de los rescates. 2.1.1. Mandas y limosnas. 2.1.2. La mendicidad. 2.1.3. La ayuda oficial. 2.2. Los rehenes. 2.3. El trueque de cautivos. 3. Mecanismos de la redención. 3.1. El oficio de alfaqueque. 3.2. La alfaquequería mayor de Castilla. 3.3. Las órdenes religiosas. 4. La apostasía. 5. Los cautivos granadinos. 5.1. Financiación de los rescates. Los bienes hábices. 5.2. Sobre los alfaqueques. 5.3. El riesgo de apostasía. 6. Para concluir. 
Tras la conquista de Antequera en 1410, el infante don Fernando inauguró la costumbre de conceder treguas al emir de Granada a cambio de la entrega de cautivos cristianos. Una exigencia que mantendrá en las treguas que suscribe hasta 1417, siendo ya rey de Aragón. La liberación de cautivos es sustituida por el tradicional pago de un tributo en metálico durante los años veinte, pero reaparece después de la etapa de guerra a gran escala que va de 1431 a 1438. En las treguas pactadas para 1439-1442 y 1443-1446, Muhammad IX se compromete a entregar un número determinado de cautivos amén del tributo correspondiente en doblas de oro. Algo parecido sucede en los primeros años del reinado de Enrique IV ${ }^{1}$.

Esta manera de recobrar la libertad sólo era posible cuando la monarquía castellana podía imponer su voluntad al adversario musulmán. También tenía un carácter aleatorio otra forma de liberación citada en las actas del concejo de Jaén: de vez en cuando algún musulmán cruzaba la frontera con la intención de convertirse, trayendo consigo a cautivos cristianos como prueba de su buena $\mathrm{fe}^{2}$.

La liberación de cautivos en la frontera granadina revistió tres formas fundamentales: la fuga, la redención mediante el pago de un rescate o un canje, y la apostasía. Ésta última era fruto de la desesperación, de la incapacidad para recuperar la libertad mediante alguna de las otras posibilidades, si bien están documentadas las conversiones por convencimiento.

Hasta ahora, los estudios sobre el cautiverio en el reino de Granada se han centrado sobremanera en las circunstancias que llevaron a muchos cristianos a perder la libertad, en sus condiciones de vida como cautivos y su posterior redención, desde una perspectiva local o comarcal. En esta ocasión pretendo abordar el problema de la liberación de cautivos sin distinción de credo y a escala de toda la frontera. Fuentes diversas, primarias y secundarias, me han permitido constatar, entre otras cosas, hasta donde castellanos y granadinos hacían uso de unos mecanismos de redención comunes; en qué medida diferían las respectivas fuentes de financiación de los rescates y cómo la apostasía fue una salida aceptable para unos y otros

\section{LA FUGA}

\subsection{RECONOCIMIENTO DEL DERECHO A ESCAPAR}

La mención más antigua de este derecho está en el tratado de vasallaje concertado por Fernando IV con el emir Nasr (Sevilla, 26/mayo/1310). El rey de Castilla promete:

\footnotetext{
* Siglas utilizadas: Archivo General Simancas (A.G.S.); Archivo Municipal Jaén (A.M.J.); Archivo Municipal Lorca (A.M.L.); Archivo Municipal Sevilla (A.M.S.)

${ }^{1}$ LÓPEZ de COCA CASTAÑER, J.E.: "El reino de Granada: ¿un vasallo musulmán? IX Congreso de Estudios Medievales, León, 2005, p. 338-339.

2 Casos documentados en 1479 y 1480. Se les recibía calurosamente y eran ayudados con limosnas. CARRIAZO y ARROQUIA, Juan de Mata: "Relaciones fronterizas entre Jaén y Granada el año 1479", Revista de Archivo, Bibliotecas y Museos (Madrid) LXI-1 (1955)32; A.M.J. Actas Capitulares 1480, f.100v. Según GARRIDO AGUILERA, Juan Carlos: "Relaciones fronterizas con el reino de Granada en las Actas Capitulares del Archivo Histórico Municipal de Jaén.”, IV Coloquio de Historia Medieval Andaluza, Almería, 1988, p. 172.
} 
"Et si algun cativo fuxiere de la vuestra tierra a la nuestra e alguna cosa truxiere, quel cuerpo dél sea quito et lo que troxiere sea puesto en rrecabdo et tornado a aquel cuyo fuere. Et estas cosas todas que sean guardadas tanbien de la nuestra tierra a la vuestra"3.

El 18 de junio de 1320 la Hermandad General de Andalucía firma con Isma il I treguas por 8 años. El capítulo que nos interesa dice: "Otrosi si algun cativo christiano fuxiere a tierra de christianos e leuase algo, quel algo que se torne a su dueño e esso mismo fagan al cativo moro que fuxiere a su tierra"4.

La misma condición se recoge en la paz de Fez (1334) y en la de Algeciras (1344): el cautivo que logra escapar recupera la libertad, pero si se diera el caso de que huyera con bienes pertenecientes a su dueño, éstos serán devueltos inmediatamente. En la paz de Algeciras se añade la posibilidad de que los fugitivos sean "pleiteados o non pleiteados"5. Es decir, que se haya concertado, negociado o tratado ya su rescate ${ }^{6}$. En la primera mitad del siglo XV se emplea la fórmula "pleyteado o non pleyteado" en el ajuste de tregua acordado en Madrid (1406) y en las treguas suscritas para 1424$1426,1439-1442$ y 1443-14467 . En cambio, la equívoca expresión "rendidos o no rendidos", es la utilizada en las treguas suscritas por el infante don Fernando, luego Fernando I de Aragón, para 1410-1412, 1413-1414, 1414-1415 y 1415-1416 ${ }^{8}$.

Habrá que esperar a la segunda mitad del siglo para que la cláusula en cuestión sea más concreta. En la tregua de 1472-1475 se habla del cautivo "rescatado o por rescatar"9. Pero son las treguas suscritas para 1477-1481 y 1481-1482 las más precisas tanto en lo referente a la situación del cautivo cuando emprende la huída como al momento en que ya se puede considerar a salvo de sus posibles perseguidores. En este sentido, leemos:

3 GIMÉNEZ SOLER, Andrés: La Corona de Aragón y Granada, Barcelona, 1908, p. 169.

4 Supra, p. 213 (nota 2). Es una petición del emir, como el resto.

5 GARCÍA FERNÁNDEZ, Manuel: Andalucia: guerra y frontera (1312-1350), Sevilla, 1990, p. 202

6 Éste es el sentido del sustantivo "pleito" y el verbo "pleitear", según CEJADOR FRAUCA, Julio: Vocabulario medieval castellano., Madrid, 1990, $2^{\mathrm{a}}$ ed., p.312.

7 El ajuste de tregua de 1406 en A.G.S. Patronato Real caja 1, f.11; la tregua de 1424, en ARRIBAS PALAU, Mariano: Las treguas entre Castilla y Fernando firmadas por Fernando I de Aragón, Tetuán, 1956, doc. 19. En la cláusula n ${ }^{\circ} 12$ del acuerdo alcanzado por don Iñigo López de Mendoza con el portavoz del emir Muhammad IX en la negociaciones de 1439, leemos: ¡... J e asymesmo en rason de los cativos que fuyeren, que se guarde la costunbre antigua". AMADOR de los RÍOS, José: Memoria histórico-crítica sobre las treguas celebradas en 1439 entre los reyes de Castilla y de Granada, Madrid, 1879, p. 130; el texto definitivo, en p. 135. La tregua de 1443, en LÓPEZ de COCA CASTAÑER, J.E.: "Acerca de las relaciones diplomáticas castellano-granadinas en la primera mitad del siglo XV", Revista del Centro de Estudios Históricos de Granada y su Reino. $2^{a}$ Época, (Granada) no 12,(1998) 27.

8 Equívoca, pues deriva de los verbos "rendir", "rendere", equivalentes a "devolver" (del latín reddere). La tregua de 1410, en GARCÍA de SANTAMARÍA, Alvar: Crónica de Juan II de Castilla, ed. Juan de Mata Carriazo, Madrid, 1982, p. 404. Los tratados de 1413, 1414 y 1415, en ARRIBAS PALAU, M.: ob. cit., docs. 8,17 y 18 .

9 TORRES FONTES, Juan: "Las treguas con Granada de 1469 y 1472 ", Cuadernos de Estudios Medievales y Ciencias y Técnicas Historiográficas (Granada) IV-V (1979) 236; GARCÍA LUJÁN, José Antonio: Treguas, guerra y capitulaciones de Granada (1457-1491). Documentos del Archivo de Frías, Granada, 1998 , p. 95. 
"Si algun christiano o moro catibo fuyere, rescatado o por rescatar, e llegare a su tierra, del mojón dentro, siete pasados, sea libre, e si fuere tomado, dentro de su tierra como dicho es, por la parte quel tal cabtibo, christiano o moro, bolviere, quel lugar primero do fuere llevado, sea obligado a los bolver (...)"

Si lleva algo que no le pertenece, será devuelto a su dueño. Pero,

"si el tal cabtivo, christiano o moro, fuere entregado de alhaqueque, quel tal no sea libre, pues que lo a de pagar el alhaqueque, y que le sea tornado a poder del alhaqueque demandándolo ya su dueño, o le sea luego fecho pagar el rescate porque se ygualó"10.

Estos acuerdos no fueron siempre del agrado de las ciudades fronterizas. El 5 de octubre de 1463, los regidores de Lorca se quejan al adelantado mayor del reino de Murcia, Pedro Fajardo, porque la tregua recientemente firmada con Granada garantizaba la libertad del cautivo que huyera a tierra de moros: "e este capítulo, señor, es a nos, que somos muy çercanos, muy perjudiçial" 11.

En la frontera suroriental, la Fuente de la Higuera destaca como punto de referencia de un sector donde la línea divisoria estaba más definida. Acaso por esto era por aquí por donde los cautivos cristianos, fugitivos de Vera, cruzaban las lindes. Sabemos de uno que ya había cruzado la laguna cuando fue visto por sus perseguidores. En otra ocasión, el dueño del cautivo fugado lo esperó en la Fuente, y pudo recuperarlo. Más llamativo es el suceso acaecido en 1474. Un cautivo cristiano huye de Vera en un mulo y es perseguido por su amo, que lo encuentra a una milla de Lorca pasada la Fuente de la Higuera. Según el testimonio prestado por un morisco en un pleito sobre límites, a comienzos del s. XVI, el fugitivo interpeló a su dueño:

"Señor, yo vuestro era, yo me he soltado y pasado el límite y mojón que hay entre Vera y Lorca, y son paces, si vos quereis quebrantar las paces me iré con vos y si no las quereis quebrantar yo soy libre, que estoy en mi tierra" ${ }^{12}$.

Los fugitivos cristianos recibieron ayuda indirecta en algunas ocasiones. Juan I ordenó instalar un faron en la torre del homenaje de la fortaleza de Alcalá la Real para orientar, de noche, a los cautivos que escaparan de Granada y lugares aledaños. En una provisión de Enrique III (Segovia, 10/julio/1392) leemos que mientras“"ardió, salieron a la vista del dicho faron muchos christianos de catiuo". Pero los fuertes

${ }^{10}$ Otra versión: "e que le sea tornado a su poder del alfaqueque demandándolo, o a su señor e le sea luego fecho pagar el rescate porque se ygualó". PEREA CARPIO, Carmen: "La frontera del concejo de Jaén-reino de Granada en 1476", Cuadernos de Estudios Medievales (Granada) X-XI (1983) 237-238; RODRÍGUEZ MOLINA, José (Ed.), Colección diplomática del Archivo Histórico Municipal de Jaén. Siglos XIV y XV, Jaén, 1985, doc. XX, p. 60-62; BONILLA, José Antonio y TORAL, Enrique: El tratado de paz de 1481 entre Castilla y Granada, Jaén, 1982, p. 31.

11 A.M.L.Cartulario 1463-1464, f. 10v. Véase VEAS ARTESEROS, Francisco de Asís y JIMÉNEZ ALCÁZAR, Juan Francisco: "Notas sobre el rescate de cautivos en la frontera de Granada", Actas del Congreso "La frontera oriental nazarí como sujeto histórico (s.XIII-XVI)”, Almería, 1997, p. 235.

12 El moro lo deja marchar no sin reclamar el mulo, que las autoridades lorquinas devolverán luego a Vera. GARCÍA ANTON, José: "Cautiverio, canjes y rescates en la frontera entre Lorca y Vera en los últimos tiempos nazaríes”, Homenaje al profesor Juan Torres Fontes, I, Murcia, 1987, p. 553. 
vientos que acostumbran a soplar en aquella zona lo derribaron circa 1387-1388, "e que estuvo así quebrado dos annos que no ardió por no fallar maestro que le fiziese". En 1390 don Alonso Fernández, señor de Aguilar y alcaide de Alcalá, pidió ayuda al rey para rehacer el faro. El monarca encargó el asunto a Francisco Bernal, recaudador del obispado de Córdoba, quien, tras varias gestiones, entregó 12.000 maravedíes a Diego Alfonso, ingeniero de Baeza, para que lo reconstruyera. Pero éste huyó del reino antes de ejecutar la tarea y sus bienes fueron embargados. Enrique III accede ahora a desembargarlos hasta la cuantía de 12.000 maravedíes, a fin de restaurar la luminaria ${ }^{13}$.

Tres años más tarde un albalá del rey al tesorero mayor de Andalucía, Alonso Fernández de Villafranca (24/mayo/1395) muestra que la obra seguía sin hacer. Enrique III le encarga que contrate a los maestros más capaces para arreglar el faro: "e lo fagades aguisar en manera que pueda alunbrar lo má ayna que ser pueda segund que primeramente alunbraua". El 3 de junio siguiente el monarca ordena a los contadores mayores de cuentas que libren al concejo alcalaíno los 3.600 maravedíes anuales que su padre había otorgado para el mantenimiento del faro: aceite, mechas y salarios de "los omnes que lo alunbren de noche $[\ldots]$ ".14.

No se sabe cuando empezó a funcionar el faro y en qué momento dejó de hacerlo. Debía estar en desuso en 1482, pues el cronista Hernando del Pulgar cuenta que el conde de Tendilla puso a sus expensas un farol nocturno en una torre de Alcalá la Real, para que los cristianos "que se soltaran de las prisiones, pudiesen venir de noche a se saluar al tino de aquella lunbre"15.

\subsection{LA INTERVENCIÓN SOBRENATURAL}

Algunas fugas resultaban tan inverosímiles que sólo podían explicarse por la intervención de la Virgen María o los santos. Los relatos sobre muros derribados, quebrantamiento de cadenas y apertura de puertas se remontan a los primeros siglos medievales. Antes de que se desarrollaran los mecanismos que hicieron factible los rescates de cautivos, la necesidad de los mismos hizo que la sociedad "creara" la primera forma de redención, la única posible, el milagro ${ }^{16}$. Más adelante, cuando la redención de los cautivos esté ya en funcionamiento, la falta de recursos para pagar un rescate hará que muchos cautivos invoquen la ayuda divina.

La santidad de Domingo, abad del monasterio de Silos (1041-1073), fue proclamada localmente después de su muerte. Algunos años más tarde el monje Grimaldo empezó a escribir la vida del santo, si bien de los tres libros conservados sólo dos son suyos y el tercero una adición posterior de sus milagros. La mayoría versan sobre cura

13 JUAN LOVERA, Carmen: Colección Diplomática Medieval de Alcalá la Real I: Transcripción de documentos, Ed. Francisco Toro Ceballos, Alcalá la Real, 1988, doc. 37, p. 60-62

${ }^{14}$ Supra, docs. 43 y 44, p. 71-73.

${ }^{15}$ Cf. Crónica de los Reyes Católicos. II: Guerra de Granada, Ed. Juan de Mata Carriazo, Madrid, 1943, p. 98. La noticia procede del capítulo CLIII de la crónica, intitulado "De las cosas que fizo el conde de Tendilla en Alhama". Es posible que el cronista confundiera Alcalá con Alhama, siendo aquí donde se erigió el faro en cuestión.

${ }^{16}$ RAMOS LOSCERTALES, José María: El cautiverio en la Corona de Aragón durante los siglos XIII, XIV y XV, Zaragoza, 1915, p. 152, nota 2. 
de enfermos, pero hay siete milagros de rescates de cautivos en tierra de moros. En todos ellos se insiste en la brutalidad de los propietarios y carceleros musulmanes ${ }^{17}$.

El culto a Santo Domingo, que se extendió a través de Castilla, León y Navarra, estaba en su apogeo en el siglo XIII, sobre todo en lo que toca al Santo como liberador milagroso de cautivos llevados al reino de Granada. Gonzalo de Berceo, que escribió entre 1225 y 1250, usa la Vita de Grimaldo como base para su Vida de Santo Domingo de Silos, en verso "cuaderna via". Para Berceo los milagros de liberación de cautivos son los más importantes en el haber de su biografiado, " $\lceil\ldots$. el que dizen de Silos que salva la frontera" 18 .

De 1232 a 1290 un monje de Silos, Pero Marin, recogió numerosos milagros del Santo, cada uno fechado con precisión ${ }^{19}$. Se esperaba que un cautivo liberado milagrosamente se presentara por iniciativa propia en Silos. Cuando llegaba, repicaban las campanas y la comunidad iba en procesión hasta la tumba del Santo a dar gracias y rezar. A menudo, los excautivos presentaban sus cadenas y las colgaban cerca. El desarrollo similar de los episodios facilitaba su fijación en la memoria colectiva según Ángeles García de la Borbolla, quien añade que las redenciones más asombrosas son aquellas en las que ni el mismo protagonista sabe como resultó liberado ${ }^{20}$. El autor parece que recoge por escrito los testimonios directos de los protagonistas, aunque son varias las manos que intervienen en la redacción. Todos los milagros se adecuan fielmente a un mismo modelo que comienza indicando la Era y termina con el día en que el cautivo liberado acude a Silos ${ }^{21}$.

Los textos de Grimaldo y Pero Marín, junto con otros materiales, fueron publicados en Madrid (1736) por Sebastián de Vergara, que había sido abad de Silos (17231725). La sección de textos suya se titula Miraculos romançados, como si diera a entender que es una traducción del latín. Pero el encabezamiento es sin duda de Vergara y no hay razón para pensar que Marin no los escribió originalmente en lengua vernácula, en la lengua que los cautivos contaban sus experiencias ${ }^{22}$. A fines del siglo

17 VALCÁRCEL, Vitalino: "La Vita Dominici Siliensis de Grimaldo”, Logroño, 1982.

18 Cf. Vida de Santo Domingo de Silos, ed. German Orduna, Salamanca, 1968, c. 3d. "Salvar la frontera" es pasarla, al otro lado, a tierra de moros, o que salva a los cristianos fronterizos. URIA MAQUA, Isabel: "El que dizen de Silos que salva la frontera (Santo Domingo3d)", Revista de Literatura Medieval, $\mathrm{n}^{\circ} 7$ (1995)159-172.(http://www.vallenajerilla.com/berceo/uria/domingosalvelafrontera.htm.) Consulta hecha el 26/enero/2012.

19 Una parte importante de los 91 milagros, que se escalonan entre 1274 y 1287 , hacen referencia a la liberación de cristianos en Granada y, ocasionalmente, en Berbería. La datación del 83'5\% de los mismos corresponde a 1280-1285, y de ellos, una amplia mayoría (51 milagros) está fechada en 1285.

${ }^{20}$ Habla de "traslaciones milagrosas". GARCÍA de la BORBOLLA, Ángeles: "Santo Domingo de Silos y las milagrosas redenciones de cautivos en tierras andalusíes", La liberazioni dei "captivi" tra Cristianita e Islam. Oltre la Crociata e il gihad: tolleranza e servizio umanitario, A cura di Giulio Cipollone, Città del Vaticano, 2000, p. 543-545.

${ }^{21}$ GARCÍA de la BORBOLLA, Ángeles: "Santo Domingo de Silos, el santo de la frontera: La imagen de la santidad a partir de las fuentes hagiográficas castellano-leonesas del siglo XIII", Anuario de Estudios Medievales (Barcelona) 31/1 (2001) 131. En las notas 12 y 14 señala las tres versiones de la fuente: Ms de la Abadía de Silos, Ms de la Real Academia de la Lengua y la copia de Sebastián de Vergara (1728-1736).

${ }^{22}$ Las cuales eran recitadas posteriormente a los peregrinos que visitaban el santuario. VERGARA, Fray Sebastián de: Vida y Milagros de el Taumaturgo español Moisés segundo, Redemptor de cautivos...Santo Domingo Manso, Madrid, 1736, p. 128-229. El manuscrito utilizado por Vergara es del s. XIV. 
pasado vio la luz la primera edición crítica de los Milagros de Pero Marín, que difiere en algunos puntos de otra publicada recientemente ${ }^{23}$.

Al lado del elemento sobrenatural está el realista, como ha demostrado $\mathrm{M}^{\mathrm{a}}$ de los Llanos Martínez Carrillo ${ }^{24}$.Según los Miraculos romançados, los cautivos cristianos trabajaban duramente. En el campo, cavando o removiendo la tierra con azadones, o tirando de los arados como si fuesen bueyes o mulas; también en la construcción, tapiando, serrando madera y haciendo yeso y, sobre todo, en la molienda manual de cereales. Las mujeres y los niños, en cambio, atendían el servicio doméstico. De noche, permanecían en casa del amo, mientras que los presos adultos eran encerrados en sitios profundos, mazmorras, antiguos silos o aljibes, con cepos y cadenas en los pies. Se les alimentaba mal con objeto de que apresuraran su redención y, en su defecto, eran maltratados ${ }^{25}$.

Los milagros de la Virgen de Guadalupe están siendo utilizados por los investigadores desde hace un cuarto de siglo más o menos. La memoria de licenciatura inédita de Pilar González Modino, Los "Milagros de cautivos" según los códices del Monasterio de Guadalupe, (Sevilla, 1984), ha sido aprovechada por M. González Jiménez y Manuel Rojas Gabriel, sobre todo por el segundo ${ }^{26}$.Isabel M.R. Mendes Drummond Braga se ha servido de las fuentes originales para su estudio sobre los cautivos y renegados portugueses en África del Norte ${ }^{27}$. Gerardo Rodríguez ha abordado posteriormente el estudio global de estos milagros con la intención, acaso, de proceder a la edición íntegra de los mismos. Los tres primeros códices de Guadalupe, que abarcan desde principios del s. XV a principios del XVI, contienen las relaciones de 163 milagros referentes al cautiverio o esclavitud. Las historias contadas siguen más o menos el mismo esquema: datos personales del peregrino; relación de su cautiverio; invocación a la Virgen y promesas; relato de la fuga, "caracterizada como una situación de sumo riesgo, pagada de aventuras y acontecimientos sobrenaturales"; por último, cumplimiento de las promesas realizadas ${ }^{28}$.

23 ANTON, Karl-Heinz: "Los Miraculos Romançados de Pero Marin”, ed. crítica, introducción e índices, Studia Silensia (Silos) XIV(1988) 12; GONZÁLEZ JIMÉNEZ, Manuel y MOLINA MOLINA, Ángel Luis: Los Milagros Romanzados de Santo Domingo de Silos de Pero Marín, Murcia, 2008.

24 MARTÍNEZ CARRILlO, María de los Llanos: "Historicidad de los Miraculos romançados de Pedro Marin (1232-1293). El territorio y la esclavitud”, Anuario de Estudios Medievales (Barcelona) 21 (1991) 69-97.

25 En casos contados, las mujeres eran tratadas como los hombres. COSSÍO, José María: “Cautivos de moros en el siglo XIII", Al Andalus (Madrid-Granada) VII (1942) 49-112; sobre la alimentación, p. 77-78; GONZÁLEZ JIMÉNEZ, M.: "Esclavos andaluces en el reino de Granada", Actas del III Coloquio de Historia Medieval de Andalucía, Jaén, 1984, p. 336-338 en particular

26 Ver, también, GONZÁLEZ MODINO, Pilar: "La Virgen de Guadalupe como Redentora de Cautivos", ÁLVAREZ de SANTALÓ, Carlos; BUXÓ, María Jesús; RODRÍGUEZ BECERRA, Salvador (Coords.), La religiosidad popular.2: Vida y muerte. La imaginación religiosa, Barcelona, 1989, p. 461-471.

${ }^{27} \mathrm{Cf}$. Entre a Cristandade e o Islao (sèculos XV-XVII). Cativos e Renegados nas franjas de duas sociedades em Confronto, Ceuta, 1998, p. 228-231.

28 RODRÍGUEZ, Gerardo: "Los milagros en la religiosidad hispánica (siglos XIII al XVI)", Bulletin du centre d'études medievales d'Auxerre/BUCEMA. Hors sèrie no 2/2008, URL: http://cem.revues.org./index 2002.Utml. Consultado el 27 de enero de 2012 
Las condiciones de vida de los cautivos son similares a las descritas en los Miraculos de Pero Marín ${ }^{29}$. Jornada laboral extenuante; encierros en mazmorras; hierros y cadenas en manos y pies; castigos corporales y morales. En cuanto a la comida, a base de cereales de poca calidad - panizo, zahina, mijo - todas las relaciones coinciden en que los presos pasaban hambre. Pero las noticias concretas escasean. El autor destaca el testimonio de Álvaro Olid, que estuvo en el "corral de Granada" unos días: allí se apiñaban 350 cautivos, algunos esqueléticos, "porque tanto era el trabajo que tenían continuamente, asy en las pascuas de los moros e otras fiestas suyas en las quales non les dexauan folgar" ${ }^{\prime 30}$.

En relación con este testimonio, Emilio Cabrera parece conforme con la distinción entre los cautivos pertenecientes al emir y los que eran propiedad de particulares, propuesta por Ferrer i Mallol. La vida de los primeros sería más penosa porque su dueño, al tener más, los hacía trabajar hasta el límite de sus fuerzas. En cambio, los cautivos en manos de particulares hacían tareas domésticas y debían de ser cuidados con más atención por sus dueños, si estos querían obtener un rescate ventajoso por ellos o, simplemente, intercambiarlos con un miembro de su propia familia cautivo en tierra de cristianos ${ }^{31}$.

Esta distinción es la única novedad en relación a la suerte de los cautivos cristianos en épocas anteriores. Los milagros de Guadalupe también recogen - como los de Silos-- casos de fugas en masa. En 1412 escapan 14 hombres de Málaga por un túnel excavado por ellos. En 1442, otros, que estaban retenidos en el "corral de Granada", aprovechan la borrachera del vigilante para irse sin alertar a los mastines. En 1448 escapan 47 cautivos de Granada: se dividen al correr la alarma, son perseguidos y cada uno cruza la frontera por donde puede ${ }^{32}$.

\subsection{LAS PRISIONES DE LOS CAUTIVOS}

Los milagros de Santo Domingo concluyen con la deposición de cadenas sobre el sepulcro del santo de Silos. En varias ocasiones es el propio santo el que lo ordena ${ }^{33}$. Los liberados acuden al monasterio de Silos en acción de gracias y dejan allí la prueba material que otorga veracidad a sus relatos: las cadenas. Aunque en el milagro 64,

29 ROJAS GABRIEL, Manuel: La frontera entre los reinos de Sevilla y Granada en el siglo XV (13901481), Cádiz, 1995, p. 212-215

30 RODRÍGUEZ, Gerardo: "La vida cotidiana de los cautivos cristianos en manos de los musulmanes. Península Ibérica-norte de África. Siglos XV y XVI”, VAL VALDIVIESO, Ma Isabel y MARTÏNEZ SOPENA, Pascual (Dirs.), Castilla y el mundo feudal. Homenaje al Profesor Julio Valdeón, II,Valladolid, 2009, p.105106 y nota 30. Álvaro Olid estuvo allí 6 días y vio morir a 4 ó 5 cautivos diariamente. ROJAS GABRIEL, M.:, ob. cit., p. 215

31 CABRERA MUÑOZ, Emilio: "De nuevo sobre cautivos cristianos en el reino de Granada.", Meridies (Córdoba) III (1996)146-147. Sigue a FERRER i MALLOL, Ma Teresa: "La redempció de captius a la Corona catalana-aragonesa", Anuario de Estudios Medievales (Barcelona) 15 (1985) 238-239. Sobre las mazmorras granadinas, véase BARRERA MATURANA, José María:"Participación de cautivos cristianos en la construcción de la muralla nazarí del Albayzin (Granada): sus graffiti”, Arqueología y Territorio Medieval (Jaén) II-1 (2004) 128-131 en especial

32 ROJAS GABRIEL, M.: ob. cit., p. 219-220.

${ }^{33}$ GARCÍA de la BORBOLLA, A.: "Santo Domingo de Silos y las milagrosas redenciones de cautivos", p. 546 
catorce cautivos trajeron el peso de sus cadenas en cera ${ }^{34}$. Se mantenían colgadas al menos por algún tiempo. Rodrigo Cerrato concluye la biografía de Santo Domingo de Silos, inserta en su Vitas Sanctorum, con una referencia a la gran cantidad de grilletes de hierro que, colgados como exvotos, se amontonan en la iglesia del monasterio, con los cuales los monjes han hecho industria y los transforman para usos diversos ${ }^{35}$.

Los Milagros de Guadalupe describen distintos tipos de ataduras: cepos, troncos o potros en el cuello; manos esposadas, encadenadas o bien atadas a maderos; pies sujetados con adobes, o hierros de diferentes pesos. Por lo general algunas de estas prisiones acompañaban a los cautivos durante las jornadas laborales. Un cautivo liberado declara que el trabajo era penoso "non solamente por las cosas que de cada día les mandavan faser más por las grandes prisiones que trayan". A la hora de huir cortaban los hierros o cadenas con una lima, un cuchillo, una hoz o bien un escoplillo, robados a sus amos ${ }^{36}$.

Los que conseguían cruzar la frontera presentaban los hierros en el santuario mariano como exvotos. En la relación del viaje de León Rosmitahl (1465), escrita por Tetzel, leemos que harían falta más de doscientas carretas para transportar el hierro depositado en el santuario extremeño ${ }^{37}$. Jerónimo Münzer, que pasa por Guadalupe en 1494, destaca que los grilletes pesaban entre veinticinco y cuarenta libras ${ }^{38}$. A mediados del siglo XVI aún había numerosos hierros y argollas colgando en las paredes, según Pedro de Medina ${ }^{39}$.

Las cadenas eran para muchos la prueba irrefutable de los milagros. El padre Juan Bautista Dameto refiere la intervención milagrosa de San Iñigo de Oña en varios casos de redención de cautivos. Y concluye:

"Sería nunca acabar, si quisiésemos referir otros milagros, a este propósito, dejolos, por no causar fastidio. Solo diré que aunque no huuiera autores algunos, que esto escriuieren, bastaran para creerlo las muchas cadenas, y grillos, que estauan antes en la capilla deste santo. El Padre Fray Toribio de Molleda (ob. 1601) [... | haziendo en el Conuento de Oña juridica información de los milagros y vida deste santo, afirmó con juramento, que en tiempo de las comunidades, y guerras civiles de Castilla, estando toda aquella tierra puesta en armas, los padres de Oña $[\ldots \mid$ temiendo que los comuneros a rio rebuelto no les hurtasen las riquezas de su casa, llamaron oficiales de herrería, y con los grillos y cadenas que estauan colgados en la Iglesia y capilla del Padre San Iñigo hizieron quatro rejas grandes, para defensa de la casa, y capilla deste Santo. Esto mismo afirma otro hombre llamado Tomás Fernández, vezino de Prendes, que aun uiúa quando se hizo la información...por aver el mismo ayudado con sus manos

${ }^{34}$ GARCÍA de la BORBOLLA, A.: "Santo Domingo de Silos, el santo de la frontera", 140

${ }^{35}$ PÉREZ EMBID, Javier: "Santo Domingo de Silos en la España del siglo XIII", Abadía.III Jornadas de Historia en la Abadía de Alcalá la Real, Alcalá la Real, 199, p. 373 y nota 10. El texto original, en apéndice (p. 376-377)

${ }^{36}$ RODRÍGUEZ, Gerardo: "La vida cotidiana...", p. 109, 111-112

37 Sigo la edición de la Hakluyt Society. Cf. The Travels of Leo of Rozmital, translated and edited by Malcolm Letts, Cambridge, 1957, p. 124

${ }^{38}$ PFANDL, Ludwig (Ed.): "Itinerarium Hispanicum Hieronymi Monetarii (1494-1495)", Revue Hispanique (Burdeos) XLVIII (1920) 107

${ }^{39}$ MEDINA Pedro de: Libro de grandezas y cosas memorables de España, Alcalá de Henares, 1595, cap. 66, f. 184 
a hazer las rejas de los grillos, y cadenas, que llegauan a número de quinientos poco más o menos" $"$.

\section{LA REDENCIÓN DE CAUTIVOS}

La redención organizada surgió en el siglo XII de la mano de reyes, municipios, órdenes militares, mercaderes y particulares. Fueron pioneros los concejos fronterizos de Castilla y Aragón, cuyos fueros se ocupan ya de la liberación de cautivos. Finalmente, en 1192 ve la luz la orden de la Santísima Trinidad y en 1218 Jaime I funda la de $\mathrm{N}^{\mathrm{a}}$ Sra de la Merced. Así se abren los cauces para la redención, siendo la financiación de los rescates el principal de los problemas; sobre todo, en el caso de cautivos sin familia o carentes de medios.

\subsection{FINANCIACIÓN DE LOS RESCATES}

El lugar de Villacarrillo se despuebla a causa de una correría de moros granadinos circa 1452. Al año siguiente, el arzobispo de Toledo, don Alonso Carrillo, dispone una derrama de 110.000 maravedíes en el Adelantamiento de Cazorla para sufragar los rescates, exceptuando a los vecinos de Cazorla y La Iruela, que habían sufrido mucho. Pero, en 1454, los concejos de Villanueva del Arzobispo e Iznatoraf informan a su señor que no han podido reunir la cantidad que les había sido repartida ${ }^{41}$.

Esta forma de solidaridad impuesta por la vía fiscal fue excepcional. A veces ni siquiera vendiendo los bienes se conseguía dinero. En tal caso, había que recurrir a la caridad pública: mandas testamentarias, ayuda de las cofradías, permisos concejiles para pedir limosna, sin excluir la posibilidad de que el concejo pagara una parte del rescate echando mano a sus rentas. Al precio del rescate había que sumar el porcentaje previo sobre el mismo cobrado por los alfaqueques, o rescatadores, y los gastos del viaje para traer al cautivo.

\subsubsection{MANDAS Y LIMOSNAS}

La cláusula sexta del testamento de Juan I de Castilla (1392) dice: "Otrosi, mandamos por nuestra anima que sean sacados de tierra de moros çient cativos, omes, mugeres e criaturas" ${ }^{2}$. La nobleza no se queda atrás: se consideraba pecado que los pudientes no contribuyeran. Aunque los señores tienden a especificar quienes son los beneficiarios de sus mandas. En 1343 Fernán González, de la antigua casa de Aguilar, legaba en testamento 3.500 maravedíes para sacar cuatro cautivos de sus villas de Aguilar, Montilla y Monturque. En 1478 Martín Fernández, Alcaide de los Donceles, ordena

\footnotetext{
${ }^{40}$ Según Fray Antonio de YEPES, Coronica General de la Orden de San Benito, Valladolid, 1617, t. VI, Centuria VI, cap. VII, f. 280-283 en particular.

${ }^{41}$ GARCÍA GUZMÁN, Mª del Mar: El Adelantamiento de Cazorla en la Baja Edad Media, Cádiz, 1985, p. 216

${ }^{42}$ LÓPEZ de AYALA, Pero: Coronica de Enrique III, Ed. y estudio por Constance L. Wilkins y Heanon M. Wilkins, Madison, 1992, p. 36
} 
sacar 6 cautivos, escogidos entre los más pobres y miserables de Lucena y Espejo. Ambos nobles se interesan por los suyos. En 1466 don Pedro Girón había otorgado 300.000 maravedíes con el mismo fin $^{43}$.

No hay testamento de la época en el que no se hagan una o varias mandas de cuantía variable, destinadas al rescate de cautivos en tierra de moros. A menudo son simbólicas, para descargo de la conciencia del moribundo, como ocurre en Córdoba. Los testamentos otorgados en Jaén (1401, 1438 y 1454) incluyen a veces una cláusula indicando que si no se puede redimir a la persona mencionada que se aplique "al primer cautivo que saliere de Jahen".

Los testamentos jerezanos datados en la segunda década del Cuatrocientos recogen dos modalidades a la hora de disponer mandas o limosnas para la redención de cautivos. La más corriente fue dejar una cantidad determinada y fija — por lo general un maravedí - que sería entregada a cada una de las instituciones beneficiarias: mercedarios, trinitarios y Cruzada. De este modo, el moribundo se ganaba el perdón de los pecados mediante indulgencias. Menos frecuente fue fijar una manda en dinero o en ganado- - que luego vendían los albaceas--, para el rescate de una persona determinada. Ocho testamentos dictados en febrero de 1414 contienen mandas de este tipo. En algún caso, el testador, previendo la muerte de su heredero directo, dispone que determinados bienes o, incluso la totalidad de su patrimonio se destine al rescate de cautivos $^{44}$.En todos ellos se incluye una cláusula para que el dinero o bienes destinados al rescate de una persona concreta cumplan su fin; si el cautivo hubiese abjurado de su fe, o hubiese recobrado ya la libertad, o estuviese muerto, se establece un orden de prelación en cuanto al beneficiario de la manda. En el testamento de Antonia Martínez (Jerez, 10/abril/1414) se destinan 50 ovejas al rescate de su tía Leonor Sánchez, pero si ésta hubiese fallecido o se hubiera tornado mora, la manda se aplicaría al rescate de los hijos de Leonor y, en su defecto, de Simón Coria o de Antón Rodríguez, vecinos de Jerez ${ }^{45}$.

Algunos documentos muestran que los donantes no confiaban en que el dinero fuera destinado al fin previsto ${ }^{46}$. El interés de los testadores porque sus mandas dieran fruto, corre parejo al que muestran en evitar que el dinero y los bienes instituidos para la liberación de cautivos beneficien a los vecinos de lugares distantes. En 1290, Sancho IV supo por la ciudad de Murcia que los procuradores de la Cruzada tomaban las mandas hechas por algunos vecinos para rescatar cautivos y las empleaban a su antojo en la redención de otros prisioneros. Por este motivo, los murcianos dudaban "en dexar ninguna cosa de lo suyo para quitar catiuos". La reacción del rey fue tajante:

“ $\lceil. .$. que el procurador de la Cruzada que lo parta a los catiuos de vuestro logar con conosçençia de los cabeçaleros daquel que fiziere la manda, et si por aventura non

${ }^{43}$ CABRERA MUÑOZ, E.: “ob. cit.”, 152

${ }^{44}$ Caso del testamento de Juan Gutiérrez (Jerez, 28 de marzo de 1414)

45 Éstos aparecen como beneficiarios en otros cinco testamentos. GARCÍA GUZMÁN, Ma del Mar y ABELLÁN PÉREZ, Juan: La religiosidad de los jerezanos según sus testamentos (siglo XV), Cádiz, 1997, p. $42-44$

${ }^{46}$ CABRERA MUÑOZ, E.: “ob. cit.”, 153 
ouiere y catiuos de vuestro logar, que den et partan a los catiuos otros que fueren de y, de la tierra, con conosçençia de los cabeçaleros como dicho es"47.

Algo parecido se plantea casi un siglo más tarde en Alcalá la Real. Una carta de Juan I (Zamora, 25/julio/1386) al concejo alcalaíno saca a relucir que las mandas instituidas por los testadores de la villa para rescatar cautivos, concernían sólo a aquellos originarios de Alcalá, algunos de los cuales habían muerto antes de ser liberados. También, que los frailes trinitarios y mercedarios iban allí y demandaban el importe de las mandas instituidas para redimir a vecinos de la villa. Cuando los moros pedían por sus cautivos sumas superiores al valor de las mandas susodichas, los frailes no las usaban para "sacar con ellas" a los cautivos alcalaínos. El rey acepta que los legados de los vecinos fallecidos se gasten en "las lavores de la dicha villa", y que no se den a los dichos frailes "ni para fuera dende" 48.

Hay que tener presente, asimismo, a las cofradías de Jerez y Jaén que reunían dinero para rescatar a sus miembros solamente ${ }^{49}$. En Córdoba encontramos la Hermandad de la Caridad de Jesucristo. Integrada mayoritariamente por artesanos, uno de ellos se encargaba de canalizar las mandas o donaciones de otro tipo: en el caso de Alonso Pérez de Baena, consta que actuó como alfaqueque, o los que iban con él. Pero la principal misión de la Hermandad era allegar fondos para hacer posibles los rescates. Desde el último cuarto del siglo XV fue cada vez más frecuente que una parte de quienes hacían testamento libraran una cantidad más o menos importante, destinada a incrementar el patrimonio de esa institución. Las donaciones engrosaban lo que algunos documentos llaman el arca de la Caridad $^{50}$.

\subsubsection{LA MENDICIDAD}

Había que pedir limosna durante mucho tiempo, yendo de un lugar a otro. Los mendigos eran a veces excautivos obligados a saldar sus deudas con quienes les habían prestado el dinero para rescatarse. El ejercicio de esta actividad requería de licencias que probasen su necesidad, evitando así la picaresca: en 1412 el concejo de Murcia persiguió a los "hombres piadosos" que pedían dinero para redimir a unos cautivos que luego morían sin salir. ${ }^{51}$.

El 14 de diciembre de 1446, Fernando de Jerez, vecino de Murcia, comparece ante el lugarteniente de alcalde en Lorca, acompañado de tres hombres y una mujer. Expone que, habiendo sido capturados por los moros tras la pérdida de Benamaurel, Alfonso Herrera - criado de Fernando Álvarez de Toledo, que fue alcaide de la plaza-los rescató en Almería. Fernando de Jerez le había entregado 50 doblas por cada

${ }^{47}$ Carta real firmada en Madrid a 27 de noviembre de 1290. TORRES FONTES, Juan: "La frontera de Granada en el siglo XV y sus repercusiones en Murcia y Orihuela: los cautivos", Homenaje a Don José María Lacarra de Miguel, IV, Zaragoza, 1977, p. 209.

48 Juan I accede a lo que le piden. Cf. Colección diplomática medieval de Alcalá la Real, 1988, doc. 32 , p. $53-55$

49 GARCÍA FIGUERAS, Tomás: "Relaciones fronterizas entre Jerez y los musulmanes de las serranías de Cádiz y Málaga”, Primer Congreso de Estudios Árabes e Islámicos (Córdoba, 1962), Madrid, 1964, p. 282

${ }^{50}$ CABRERA MUÑOZ, E.: “ob. cit.”, 154-155

51 TORRES FONTES, J.: "La frontera de Granada en el siglo XV”, p. 197 
varón y 60 por la mujer, o sea 210 doblas. Pide un certificado porque si "el dicho Alfonso de Ferrera no quisiere dar el dicho rescate, que a él e a ellos es neçesario buscar entre las buenas gentes el dicho rescate". El alcalde lorquino accede a darles el testimonio solicitado ${ }^{52}$.

Reunido el concejo de Jaén el 13 de marzo de 1476, se presentan los parientes de Gonzalo Ruiz, que lleva 5 años cautivo en Guadix, y declaran que "por ser él pobre no tenía con que lo sacar del dicho cativo sin ser ayudado de las limosnas de las buenas gentes". El concejo les proporciona una carta de fe "para demandar las dichas limosnas por todos los reinos". El 24 de mayo de aquel mismo año dan otra a la vecina Catalina Ruiz, por su hijo Bartolomé, cautivo en Granada ${ }^{53}$. En septiembre de 1488 se conceden otras tres licencias. El día 5 a Juan de la Hoya; preso en Guadahortuna hará un año, se rescató por 15.000 maravedíes, "por los quales dio fiança e es pobre e no tiene tierra ni (...)"; el día 19, licencia a Blanca Rodríguez, para sacar de cautiverio a su hijo Pedro Duque, apresado veinte días antes y llevado a Granada, donde se rescató por 7.250 maravedíes "con los derechos". El 22 de septiembre se discute el caso de Alonso Fernández de Cazorla, apresado hacía 2 años en una entrada en tierra granadina, con otros seis, y que salió de cautiverio tras haber pagado 15.000 maravedíes, "con los derechos". Gracias al testimonio de Juan de la Hoya, que lo vio cautivo, le dan carta para pedir limosna ${ }^{54}$.

\subsubsection{LA AYUDA OFICIAL}

Juan de Salazar, criado real y vecino de Tarifa, tuvo más facilidades. Los Reyes Católicos ordenan (Segovia, 20/enero/1475) a todos los concejos del reino que además de procurarle posada conveniente y gratuita, le entreguen buena parte de las mandas que hayan recaudado para la redención de cautivos y diputen a dos jurados y dos hombres buenos para que pidan limosna en su localidad, de manera que aquél pueda pagar la mitad que le resta del precio convenido para el rescate de sus dos hermanos, presos aún en el reino de Fez, a donde fueron conducidos los tres cuando los comendadores de Sabiote y de La Membrilla "entraron a tierra de moros e se perdieron" ${ }^{5}$.

El concejo de Murcia tenía un tercio de rentas de la tahurería asignadas al rescate de cautivos desde el reinado de Alfonso X el Sabio ${ }^{56}$. A principios del siglo XV este mismo concejo exime a veces de impuestos directos a la familia de un cautivo, le da una ayuda en metálico o pone a los niños a trabajar. Por su parte, el concejo de Sevilla concede limosnas en casos concretos ${ }^{57}$.El 19/septiembre/1488 el concejo de Jaén entrega 500 maravedíes del "fondo de las penas" a un tal Juan López ${ }^{58}$. En el caso de

${ }^{52}$ VEAS ARTESEROS, F.A. y JIMÉNEZ ALCÁZAR, J.F.: “ob. cit., p. 231

${ }^{53}$ A.M.J. Actas Capitulares 1476, f. 62 v. y 130 r. GARRIDO AGUILERA, Juan Carlos: “ob. cit.”, p. 168

${ }^{54}$ A.M.J. Actas Capitulares 1488, f. 2v., 14r. y 15v. GARRIDO AGUILERA, J.C.:"“ob. cit., p. 172

${ }_{55}$ A.G.S. Registro General del Sello, enero 1475, f. 184

56 Según leemos en una carta de su bisnieto Alfonso XI (Sevilla, 3/octubre/1332) en relación con la denuncia presentada por Rodrigo Ballesteros, vecino de Murcia. Habían prometido darle 300 maravedíes al salir del cautiverio, pero la entrega del dinero se retrasa porque había otros demandantes "que deven ser antes pagados". TORRES FONTES, J.: "La frontera de Granada en el siglo XV...", doc. 1 del Apéndice, p. 209

${ }^{57}$ ROJAS GABRIEL, M.: ob. cit., p. 227

${ }^{58}$ A.M.J. Actas Capitulares 1488, f. 14 r. GARRIDO AGUILERA, J.C.: “ob. cit.”, p. 172 
esta ciudad también el rey ayudaba. En 1473 Enrique IV exime del pago de monedas a la mujer e hijos de los vecinos cautivos, que tampoco han de pagar almojarifazgo por la cuantía de su rescate ${ }^{59}$.

Los cautivos de condición nobiliaria contaron siempre con ayudas especiales. Juan de Saavedra, apresado en marzo de 1448 en Río Verde, concertó el rescate en 12.000 doblas de oro castellanas (1.850.000 maravedíes). Como su fortuna no alcanzaba para cubrir esa suma, hubo de entregar dos hijas en rehenes mientras su hermano Gonzalo, alcalde de la justicia y caballero veinticuatro de Sevilla, conseguía 100.000 maravedíes del concejo hispalense y otros 250.000 del rey Juan $\mathrm{II}^{60}$. Don Juan Manrique, conde de Castañeda, capturado en la frontera de Jaén el 11 de agosto de 1456, estuvo preso 17 meses. Enrique IV pagará la tercera parte de las 60.000 doblas castellanas (9.000.000 de maravedíes) que los moros pedían por su rescate ${ }^{61}$.

A veces, cuando la codicia del adversario retrasaba la liberación de un cautivo la coyuntura política favorecía su salida antes de lo previsto. El emir de Granada dejó marchar a la mujer e hijo de Diego Riquelme, miembro de la oligarquía murciana, a cambio de entregarle a unos embajadores enviados por el régulo de Bona a la corte de Renato de Anjou. Viajaban éstos a bordo de la nave de Jean de Baux, que fue apresada por un corsario castellano a la altura de Ibiza y llevada al puerto de Alicante. Diego Riquelme los compra con su anuencia a fin de sacar a los suyos, que llevan mucho tiempo cautivos "e por dineros ningunos no los podían hauer redimido, saluo agora que, por troque destos moros, plugo al dicho rey /de Granada/ dar los dichos catiuos cristianos $(\ldots)^{\prime \prime 62}$.

\subsection{LOS REHENES}

No era raro que los propios cautivos se encargasen de reunir el dinero exigido por su rescate, previa entrega de rehenes a sus amos. Los hombres de religión granadinos no veían mal que se permitiera a un cautivo cristiano volver a su tierra con tal fin, dejando como rehén a un hijo o un hermano menor, que pasaría a ser esclavo del dueño si el cautivo no volvía. Algunos aconsejaban que se eligiera como rehén a un hombre adulto antes que a un menor ${ }^{63}$.

En la práctica, sin embargo, se dejaba como rehenes a hijos e hijas de corta edad. Una solución muy dura para don Miguel de Cetina, que había sido apresado por los musulmanes y llevado a Málaga. Incapaz de soportar los malos tratos a los que era sometido concertó con su dueño rescatarse por cien doblas, dos aljubas verde oscuro

${ }^{59}$ ARGENTE del CASTILLO, Carmen: "Los cautivos en la frontera entre Jaén y Granada", IV Coloquio de $H^{a}$ Medieval Andaluza, Almería, 1988, p. 216

${ }^{60}$ SECO DE LUCENA PAREDES, Luis: "La historicidad del romance "Río Verde, Río Verde", $A l$ Andalus, (Madrid-Granada) XXIII (1958) 90 y ss.

${ }^{61}$ LÓPEZ DAPENA, María Asunción: "Cautiverio y rescate de don Juan Manrique, capitán de la frontera castellana (1456-1457)", Cuadernos de Estudios Medievales (Granada) XII-XIII (1984) 243-253

${ }^{62}$ Los RRCC acceden a la petición de Riquelme. La historia de este trueque está inserta en la respuesta de Fernando e Isabel (Toledo, 29/abril/1480) a una reclamación presentada por Renato de Anjou, cuya conformidad reclaman. Cf. Documentos sobre relaciones internacionales de los Reyes Católicos, Ed. Antonio de la Torre, I, Barcelona, 1949, p. 94-95

${ }^{63}$ Infra $\mathrm{n}^{\mathrm{o}} 72$ 
y dos cuchillos de Pamplona, dejando a dos hijos en calidad de rehenes. Según el milagro $\mathrm{n}^{\circ} 72$ de la colección de Santo Domingo de Silos:

"El auendo fecho este pleito, estaua en muy grand cueyta, que si los fijos metiesse en rehenes él non abria de qué los podies quitar tan ayna, e si él muriés en este comedio que nunqua se quitarían los fijos. Començó de rogar llorando de los oios muy fuertemente e acomendarse a Dios e a Santa María e a Santo Domingo que le ouiessen merçed e que le sacasen de aquellas cueytas en que estaua, porque non perdiessen los fijos" 64 .

En los fueros de Iznatoraf, Baeza y Úbeda (siglo XIII) se prohíbe bajo pena de muerte entregar a un hijo como rehén en tierra de moros, si no lo manda el concejo; y en el caso de las hijas, ni aun mandándolo y con el agravante de que el culpable moriría en la hoguera. Pero en la reunión del concejo de Jaén celebrada el 4 de octubre de 1479 , los regidores acuerdan que una muchacha sea entregada "en tierra de moros" como garantía, mientras se rescata a un tío suyo ${ }^{65}$

Los rehenes de la nobleza eran bien tratados. En el cartulario de Francesco Spinola, mercader genovés residente en Málaga, aparece registrada la venta de un tejido, o quizá, de una piel trabajada, a domina Catalina captiva in Lambra Garantís en 1436, una señora que no he podido identificar ${ }^{66}$. Diego Hernández de Zurita, alcaide de Arcos, fue apresado por los musulmanes en 1438 y llevado a Granada. De allí volvió para reunir 2.250 doblas que debía de su rescate, no sin antes dejar como rehenes a su hija I nés, a Catalina Calderón, su doncella, y a su sobrino Lorenzo ${ }^{67}$. Las noticias sobre Micer Lucía y Micer Bartolomé, genoveses de Granada que negociaban en la frontera de Jaén circa 1478-1480, están relacionadas con ciertas gestiones hechas para liberar a $\mathrm{D}^{\mathrm{a}}$ Aldonza de Benavides, hija del señor de Jabalquinto y regidor de Baeza, Juan de Benavides. Según parece, la muchacha había sido llevada a Granada como rehén mientras su padre saldaba cierta deuda ${ }^{68}$

\footnotetext{
${ }^{64}$ GONZÁLEZ JIMÉNEZ, M. y MOLINA MOLINA, A.L.: ob. cit., p. 144

${ }^{65}$ "Este día, por quanto Juan de Lara está obligado de levar a Granada con el alhaqueque, a poder de Abrahen de Mora, a Ana de Lara, su fija, por 34 doblas de Muley del rescate de Rodrigo de la Corredera, su cuñado, que sacó de cativo, e el plazo que la avía de levar es pasado, e dis más, e no la levó, e el dicho moro demanda agora las dichas 34 doblas, e para la paga dellas, por mandamiento de los dichos señores, se venden los bienes del dicho Juan de Lara e de su muger, e porque no se fagan prendas en veçinos desta çibdad, ordenaron e mandaron de entregar a la dicha Ana, su fija al dicho moro por las dichas 34 doblas, e que la lieve Martín de Lara, alhaqueque, a Granada; e no se vendan los bienes esos, por quanto los dichos Juan de Lara e su muger están obligados ante mí el dicho escrivano a la sacar de cativa a la dicha su fija”. CARRIAZO y ARROQUIA, J. de M.: “ob. cit.", 39-40

${ }^{66}$ La operación se hizo a través de Branchaleone Spinola, que servía a Francesco de interlocutor en sus relaciones con los mercaderes granadinos, judíos o musulmanes. Archivio Durazzo-Giustiniani, Sección Sauli, reg. 1839, fols. CVIIIIv y CXV recto. Debo este dato a la amabilidad de la Dra. Adela Fábregas. No he podido identificar a esta cautiva. Giovanna Petti-Balbi supone, sin fundamento, que era una concubina del emir. Cf. "Le strategie mercantili di una grande casata genovese: Francesco Spinola tra Bruges e Malaga (1420-1456)", Serta Antiqua et Mediaevalia, (Génova) I (1997) 387

${ }^{67}$ SANCHO de SOPRANIS, Hipólito: "Don Diego Fernández de Zurita, alcaide de Arcos, embajador en Granada", Revista de Historia y Genealogía Española, 2a época (Madrid) III (1929) 330-331

${ }^{68}$ Los documentos no aclaran si se trataba de un rescate sin pagar. A.G.S. Registro General del Sello, mayo 1478, f.40; junio 1480, f. 97 y 161. CARRIAZO y ARROQUIA, J. de M. : "ob. cit.", 44.
} 
El riesgo de que renegaran de la fe aumentaba, en cambio, con las gentes del común. Un joven de Lorca fue llevado a la Fuente de la Higuera para ser entregado como rehén de su padre, permaneciendo en esa condición cinco años y medio. Un vecino de la misma ciudad fue apresado por los moros de Vera. El ejea lorquino lleva a su hijo a la Fuente del Pulpí - otro lugar de encuentro habitual--, a donde acude el ejea de Vera solo, pues el cautivo se había negado a aceptar a su hijo como rehén "porque los moros no le tornasen moro, como era muchacho ${ }^{69}$

Por eso significaba tanto que algunos de estos rehenes pudieran escapar. Caso del nieto de Alonso García, vecino de Écija, que estaba por rehén de su abuelo en Antequera, en el año de 1409-tenía 10 u 11 años de edad--, y de otro mozuelo, de 9 años, que estaba allí por rehén de un hermano suyo. Ambos se fugaron una noche y tras andar perdidos dos días, sin comer y con el ánimo por los suelos, dieron con una hermosa señora que les invitó a acompañarla hasta Teba. Al difundirse esta historia, en Écija entendieron que había sido la Virgen del Valle, patrona de la ciudad, quien había obrado un milagro y así se lo escribieron al maestre de Santiago y al infanteregente don Fernando ${ }^{70}$.

\subsection{EL TRUEQUE DE CAUTIVOS}

Sucedía a menudo que los granadinos no querían dar sus cautivos si no era mediante canje con un correligionario preso en Castilla, a menudo pariente suyo. La razón de esta postura era religiosa. Aunque el Corán no prohíbe categóricamente los rescates de los cautivos infieles, muchos faquíes preferían intercambiarlos por cautivos musulmanes. Algo parecido sucede con las mujeres y los niños: canje antes que rescate. Tratándose de menores de edad, algunos "hombres de religión" exigen que para que sean rescatados, han de estar acompañados por sus padres ${ }^{71}$. En lo que toca a alAndalus, leemos en el formulario notarial de Ibn Salmunn las siguientes opiniones: ${ }^{72}$

a)- No debe aceptarse dinero por el rescate de un cristiano si es posible canjearlo por un musulmán cautivo en la casa de los infieles. b)-Los menores de edad, acompañados de sus padres, correrán la misma suerte que éstos. Si están solos, no se permitirá su rescate si no es por fuerza mayor y en caso de trueque por otros cautivos musulmanes.

${ }^{69}$ GARCÍA ANTON, J.:“ob. cit.”, I, p. 558.

${ }^{70}$ GARCÍA de SANTAMARÍA, Alvar: Crónica de Juan II, capítulo 130, p. 282-283.

71 BENREMDANE, Ahmed: "Al-Yihad y la cautividad en los dictámenes jurídicos o fatuas de los alfaquíes musulmanes y de al-Wansarisi, en particular: el caso de los musulmanes y de los cristianos de al-Andalus", La liberazione dei "captivi" tra Cristianità e Islam. Oltre la Crociata e il Gihad: tolleranza e servizio umanitario, A cura di Giulio Cipollone, Città del Vaticano, 2000, p. 454-455; HASNAOUI, Milouda: "La ley islámica y el rescate de cautivos según las fetuas de al-Wansarisi e Ibn Tarkat", Ibidem, p. 554-555; también se ocupa de los tipos de cautivos, etc: PECHERGUI, Ahmed: "Les precèptes des captifs en Islam", Ibidem, p. 655-659.

72 VIDAL CASTRO, Francisco: "El cautivo en el mundo islámico; visión y vivencia desde el otro lado de la frontera", II Estudios de Frontera. Actividad y vida en la Frontera (Alcalá la Real, 1997), Jaén, 1998, p. $777-778$. 
Según el milagro $n^{\circ} 69$ de la colección de Santo Domingo de Silos, un tal Juan de Segura fue comprado por el moro Algalan, que tenía a su hijo Maçot cautivo en Segura de la Sierra. Por eso

"metió a este Iohan /de Segura/ en grandes fierros (...). Así como lo açotauan, ouo de façer pleyto que se quitasse, e pleteó por XL uaras de Yprès, e que fiçiese dar su fijo Moçot, que tenía el conçejo de Segura e ouo de façer tal carta sobre sí, que pagase esto sobre dicho, e quel diesse el fijo a día sennalado. E este Iohan non avía de qué pagar nin sabía qué façer. Començó de llorar (...)"’33.

Los familiares de cautivos cristianos se veían obligados a buscar y llegar a un acuerdo con el dueño del cautivo granadino correspondiente. Esto se prestaba a abusos por parte del propietario del moro que se intentaba comprar. Por eso, en fecha temprana comenzó a gestarse una normativa que obligaba a los dueños de esclavos moros a facilitarlos a las personas que los necesitaran para trocarlos por un cristiano. Según los fueros de Iznatoraf, Baeza y Úbeda, los dueños de esclavos debían facilitarlos a las personas que los quisieran para trocar por un cautivo, devolviéndoles el precio que pagaron por ellos, más 10 maravedíes de ganancia ${ }^{74}$.

En el Adelantamiento de Cazorla se establece a principios del siglo XV que el propietario del moro canjeable por un vecino preso en Granada, sólo pueda pedir un tercio más de lo que le había costado ${ }^{75}$. Posteriormente, la ciudad de Lorca dispuso de una ordenanza y estatuto similar: los vecinos propietarios de cautivos moros del reino de Granada "que fuesen nesçesarios para sacar a algund catiuo christiano", podían ser privados del mismo por el concejo, "dándole el terçio de ganançia más de lo que le costó". En 1459 la ciudad de Murcia adoptó esta ordenanza con algunas restricciones para los dueños de moros susceptibles de ser canjeados, incluyendo a los forasteros que los comprasen en Murcia: no podrían llevárselos sin dar garantías al concejo "que sy el dicho moro fuere neçesario para sacar de catiuo del dicho regno de Granada qualquier cabtiuo christiano vezino de la dicha çibdad, que lo tornará a ella". La ordenanza fue modificada en algunos puntos por el Consejo Real antes de que la confirmase el monarca. El concejo podrá tomar el cautivo moro demandado para un trueque "de poder de aquel que lo toviere, dándole el terçio de ganançia más de lo que le costó sy por menos presçio non lo quisiere vender", tras averiguar lo que había pagado realmente por el cautivo. Si su dueño lo había obtenido en una cabalgada "o en otra qualquier manera", exceptuando la compra, "e fuese neçesario el tal moro para el rescate o troque de algund christiano desta dicha çibdad", en tal caso el corregidor se encargará de tasar y apreciar el valor del moro en cuestión antes de indemnizar a su propietario ${ }^{76}$.

73 GONZÁLEZ JIMÉNEZ y MOLINA MOLINA, A.L.: ob. cit., p.139. Los Milagros de Guadalupe ofrecen muchos ejemplos de la práctica del trueque ("destroques"). RODRÍGUEZ, G.:"La vida cotidiana de los cautivos cristianos...", p. 107.

74 ARGENTE del CASTILLO, Ma del C.: “ob. cit.”, p. 216.

75 GARCIA GUZMÁN, Ma del M.: ob. cit.., p. 213-214.

76 Véase la provisión real fechada en Madrid, a 12 de diciembre de 1459, publicada en Documentos de Enrique IV, Ed. Ma del Carmen Molina Grande, Murcia, 1988, doc. 114, p. 259-261. 
En las Cortes de 1462 se acordó que el amo de un moro o mora que fuese reclamado para canjearlo por algún cautivo cristiano, lo diera por un precio razonable: lo que le hubiese costado más un tercio, si lo había tenido en su poder menos de un año; o la mitad de lo que le costó si lo tenía de antes. Pero si el moro le pertenecía por derecho de guerra, podía pedir por él lo que estimara conveniente. En el caso de que fuesen vendidos en pública almoneda, tendrían preferencia quienes los compraran para liberar cristianos e, incluso se podrían adquirir a sus nuevos daños durante los dos meses siguientes a la subasta, dándoles la misma cantidad que pagaron por ellos y jurando que los compraban para redimir a cautivos cristianos ${ }^{77}$.

La aplicación de esta normativa en toda la frontera no evitó que se cometiesen numerosos abusos. En 1463 ya hubo problemas con Juan Mellado, vecino de Lorca, propietario de un moro que los de Vera pretendían canjear por un fraile y 30 doblas. Pese a la intervención del adelantado del reino de Murcia y las presiones del concejo lorquino, Mellado se negó a entregarlo si no le abonaban un tercio más de lo que había pagado por él ${ }^{78}$. En noviembre de 1478 los Reyes Católicos intervienen a petición de la mujer de Pedro de la Dueña, cautivo, por cuya liberación los granadinos exigieron a un correligionario que tenía Pedro de Reinosa, vecino de Écija ${ }^{79}$. Ese mismo año Fernando e Isabel amparan de forma expresa a los hermanos de la Caridad de Jesucristo en el uso de las prerrogativas dadas por las cortes de Toledo de 1462. Lo que nos da a entender que, aparte de allegar y administrar el dinero necesario para los rescates, también se ocupaban de trocar cautivos ${ }^{80}$.

Un caso dramático es el de Gonzalo Marín, vecino de Cieza. Los Reyes Católicos ordenaron a las autoridades judiciales de Murcia, Úbeda, Baeza y la villa de Beas que averiguasen si Catalina Halcón, su esposa, estaba cautiva en el reino de Granada, en poder de Muley Nacer. Debían indagar, asimismo, a qué precio obtuvo el moro del que el peticionario pretende aprovecharse para rescatar a su mujer, la persona en cuyo poder se encuentra. Una vez sabido, y, según lo aprobado por el

77 Cf. Cortes de los antiguos reinos de León y Castilla, ed. Real Academia de la Historia, III, Madrid, 1866, Cortes de Toledo (1462), capítulo 54, p.742-743; RODRÍGUEZ MOLINA, J.: ob. cit. , doc. VII, p. 28. A veces se daban situaciones no contempladas, que yo sepa, ni en éste ni en ningún otro ordenamiento. Rodrigo de Maliano, vecino de Maliano, tenía en la ciudad de Murcia un moro cautivo, Hamete de Vera, "e teniéndole rescatado por çiento doze doblas moriscas a preçio de çiento e quinze maravedíes cada una", el concejo le tomó por la fuerza el mentado cautivo diciendo que lo necesitaba "para fazer çierto troque por un christiano". Hasta la fecha le habían pagado 7.000 maravedíes a cuenta de su rescate y, si bien Maliano no dejaba de reclamar los 5.880 maravedíes restantes, la respuesta era ninguna. Recurre a la justicia real y el monarca ordena a las autoridades concejiles que le paguen lo que le deben o le devuelvan el cautivo moro. Por su parte, Rodrigo de Mediano devolverá lo que había cobrado pagándole, empero, 4.000 maravedíes en costas. Provisión real fechada en Valladolid, el 4 de abril de 1460. Cf. Documentos de Enrique IV, doc. 126, p. 291-292.

78 Ver documento fechado en Lorca a 5/septiembre/1463. A.M.L. Cartulario 1463-1464, f. 10v. Según VEAS ARTESEROS, F.A. y JIMÉNEZ ALCÁZAR, J.F.: “ob. cit.”, p. 231, nota 8.

79 Ver provisión fechada en Córdoba a 5 de noviembre de 1479, en A.G.S. Registro General del Sello noviembre 1479, f. 124. Al año siguiente, un vecino del Puerto de Santa María presenta una reclamación similar, según provisión real dictada en Toledo, el 24 de abril de 1480. Ibidem, abril 1480, f. 137. Cita ambos casos ROJAS GABRIEL,M.: ob. cit., p. 229.

${ }^{80}$ CABRERA MUÑOZ, E.: “ob. cit.,155. 
rey Enrique en las cortes de Toledo de 1462, harán que, pagando Gonzalo Marín el precio debido, le sea entregado el susodicho moro ${ }^{81}$.

La ordenanza enriqueña se recoge en las actas capitulares del concejo de Jaén (1476) como recordatorio a la villa de Alcalá la Real, que se niega a cumplirla ${ }^{82}$. El 16 de diciembre de 1476, reunido el concejo, un hijo de Hernando Martínez, cautivo en Granada, declara que no puede salir sin comprar un moro que tenía el canónigo Gonzalo Díaz, "el qual no lo quiere dar salvo a troque de un potro" que tiene un hermano del citado cautivo ${ }^{83}$.

Había una solución extrema para quienes no podían comprar un cautivo granadino por falta de recursos. "Movido por caridad e compasión", el condestable don Miguel Lucas de Iranzo cruza la frontera el 9 de septiembre de 1461. Los expedicionarios - alrededor de cien jinetes - corren con éxito los campos de Íllora pues matan a veinte moros y vuelven con otros treinta, cautivos. Escribe Escavias:

"Y así traydos, como el dicho señor Condestable oviese ynformaçion quien e quales eran las personas que tenían sus maridos, o padres, fijos o hermanos o otros parientes cativos, de aquella çibdad de Jahen, y que más miserables eran, a cada uno de aquellos mandó dar su moro, con que podiese sacar su pariente. Y desta cabsa, muchos salieron a tierra de cristianos, /que/ no tenían esperança de salir ni nunca salieran. Y, mal pecado, pudiera ser que algunos dellos, con desesperaçion de la mala vida, renegara de la fe, como otros han fecho en tal caso como éste" ${ }^{84}$.

\section{MECANISMOS DE LA REDENCIÓN}

La palabra alfaqueque es de origen árabe (al-faqqaq o "enviado" y "redentor de cautivos"). En Castilla es mencionada por vez primera en Las Partidas, II.3.1-3, donde se especifican las cualidades y deberes de quienes desempeñaban el oficio de alfaquequería. Pero había aparecido antes en Aragón, como exea y almotalefe (también de origen árabe), en el fuero de Belchite $(1116)^{85}$.

${ }^{81}$ Catalina Halcón había sido capturada junto a su esposo, sus dos hijos y otros cristianos en una entrada hecha por el emir de Granada a la villa de Cieza en abril de 1477 y, aunque el marido vendió toda su hacienda y se rescató a sí mismo y a sus hijos, no tuvo suficiente para pagar el rescate de su esposa, pues el moro que la tenía cautiva demandaba por ella 300 doblas. A.G.S. Registro General Sello, junio 1480, f. 227

82 GARRIDO AGUILERA, J.C.: “ob. cit.”, p. 166 y 168-169

83 Recibe licencia para vender el animal por 5.500 maravedíes. A.M.J. Actas Capitulares1476, f.235r. GARRIDO AGUILERA, J.C.: “ob. cit.”, p. 169. Otros casos registrados en las actas gienenses, en Ibidem, p. 166 y $168-169$

${ }^{84}$ Cf. Hechos del Condestable don Miguel Lucas de Iranzo, ed. Juan de Mata Carriazo, Madrid, 1940, p. 68

85 BRODMAN, John W.: "Municipal Ransoming Law on the Medieval Spanish Frontier", Speculum 60 (1985) 318-330 


\subsection{EL OFICIO DE ALFAQUEQUE}

Los alfaqueques se encargaban de poner en relación a los poseedores del cautivo con sus familiares para concertar el rescate ${ }^{86}$. Cobraban por sus servicios entre el $10 \%$ y $12 \%$ del valor del rescate, en metálico. En el caso de aquellos que estuvieron destacados en Gibraltar, Castellar, Zahara y Antequera a fines del siglo XV, se sabe que percibían 7 ' 5 doblas por cada rescate y que el cautivo, moro o cristiano, pagaba $2^{\prime} 5$ doblas "de puertas e hierros" al alcaide del lugar por donde saliera ${ }^{87}$

Hoy nos puede sorprender que en noviembre de 1455 las autoridades de Ronda dejaran que un alfaqueque jerezano se llevara a un cautivo cristiano con la promesa de devolverles una mora prisionera en Arcos. Una muestra, sin duda, del crédito y estima que tenían estos intermediarios en las operaciones de rescate. La documentación de la frontera occidental refleja que el método habitual para conseguir el rescate de cautivos era a través de la intercesión de los alfaqueques. En teoría, al menos, las ciudades y villas próximas a la linde fronteriza disponían de alfaqueques concejiles, cuyas normas de actuación se regían por las Partidas alfonsinas ${ }^{88}$.

La Partida II, tit. XXX dedica tres leyes a definir la misión, obligaciones y derechos de los alfaqueques profesionales. En concreto, han de reunir seis condiciones: Bona fide; no ser codiciosos; conocer la lengua del adversario; no ser mal queriente, pero sí esforzado y sufrido; tener bienes propios para garantizar rescates. Ha de portar documentos que lo acrediten y viajar por los caminos principales, dando cuenta de lo que llevan antes de partir. Finalmente, para evitar que se beneficien de su posición se abstendrán de comerciar ${ }^{89}$.

Cruzaba las lindes con un acompañante, provisto de un salvoconducto expedido por las autoridades del lado contrario. Es probable que los pasaportes expedidos por los granadinos tuvieran el carácter de aman, que obligaba al beneficiario (musta'min o portador del aman) a abstenerse de decir o hacer algo que pudiera ser interpretado como una falta de respeto al Islam. El aman podía ser otorgado por el emir, por la autoridad en la que éste delegase e incluso por un simple particular ${ }^{90}$.

En octubre de 1374 el alcaide y aljama de Vélez Rubio pidieron al concejo de Murcia que asegurase a su alfaqueque "Mahomat Alahieni" para que "en todo tienpo él e su omne e amos a dos en uno, que vayan e vengan en fecho de los cativos cristianos e moros segund se solía fazer sienpre a los alfaqueques". A cambio, ofrecían hacer lo mismo con el alfaqueque murciano. El concejo respondíó el 3 de noviembre

86 Aparte de este sistema, Carriazo detectó otro en el área de Jaén: de concejo a concejo, negociación pública mediante "oficiales", se exponen quejas y se pactan compensaciones. Cf. "Relaciones fronterizas entre Jaén y Granada el año 1479”, p. 39. La misma situación - trato directo o uso de alfaqueques - sale a relucir en las actas del concejo de Jerez, siendo más numerosos los alfaqueques musulmanes que los cristianos. Cf. GARCÍA FIGUERAS, T.: “ob. cit.”, p. 280.

${ }^{87}$ LÓPEZ de COCA CASTAÑER, J.E.: "Andalucía y el norte de África: la redención de cautivos a fines de la Edad Media", Actas del III Congreso de Historia de Andalucía, Córdoba, 2003, p. 280.

${ }^{88}$ ROJAS GABRIEL, M.: ob. cit., p. 230.

89 TORRES FONTES, J.: "Los alfaqueques castellanos en la frontera de Granada”, Homenaje a D. Agustín Millares Carlo, II, Las Palmas de Gran Canaria, 1975, p. 99 y ss.

${ }^{90}$ LÓPEZ de COCA CASTAÑER,, J.E.: "Institutions on the Castilian-Granadan Frontier, 1369-1482", BARTLETT, Roger y MACKAY, Angus (Eds.), Medieval Frontier Societies, Oxford, 1989, p. 139-140. 
otorgando una carta de seguro para el alfaqueque velezano "con todo lo que troxiere aquí, a esta dicha çibdad, él e su omne con qualquier cosas que troxieren". La carta concluye así:

"E porque desto seades vos e él çierto, enbiamos vos esta nuestra carta abierta e sellada con nuestro sello mandadero, porque es menester que otra tal carta de aseguramiento como ésta nos enbiedes vos para Berenguer Sarañana, nuestro alfaqueque, para que él e su omne puedan yr allá e estar e venir salvos e seguros".

Algo debió ocurrir, sin embargo, para que la ciudad de Murcia escribiera al emir dos meses más tarde, el 3 de enero de 1375, acerca de Berenguer Sarañana. Éste había ido algunas veces a Vera y Vélez amparándose en las cartas de seguro de sus alcaides y aljamas, y "non osava yr allá bien seguro" sin tener una carta firmada por el emir. El concejo la pide para que el mentado alfaqueque

"pueda yr e venir por todo el vuestro señorío en fecho de los cativos él e otro omne con él, con todo lo que levare e troxiere salvo e seguro, de día e de noche, por caminos e por las villas, tan bien en guerra como en paz segunt uso de alfaqueques"91.

No se ha conservado la respuesta del emir Muhammad V, si es que la hubo. Pero sabemos de un salvoconducto otorgado por Abu l-Hasan 'Ali (1484) a Hernando de Figueroa, vecino de Bornos, a quien califica de "virtuoso, nonbrado, caritativo, de buenos respetos y aprobada vida e costunbre, de noble, linpio y generoso nacimiento". Le concede el aman en su calidad de "rescatador" del rey de Castilla, para liberar los cristianos que están presos en los lugares de su reino, "así como por la misma horden que lo ha acostunbrado hacer en los próximos años pasados, con la seguridad, honrra y confianza que es razón y merece la calidad de su persona"92.

El "uso y costunbre" de la frontera prescribía que los alfaqueques se desplazaran por los caminos reales y no por descampados, exhibiendo un pendón que los identificase-real, señorial o propio-- y haciendo sonar regularmente la trompeta. Esto contradice a quienes sostienen, equivocadamente, que los alfaqueques castellanos solían vestir como musulmanes y, para parecerlo, se dejaban crecer la barba ${ }^{93}$. El error procede de una lectura incorrecta del artículo octavo de las ordenanzas de la alfaquequería mayor de Castilla dictadas por la reina doña Juana en $1514^{94}$. Este artículo condena a los alfaqueques que habiéndose comprometido a redimir un número

${ }^{91}$ TORRES FONTES, J.: “Los alfaqueques...”, docs. 1-3 del Apéndice, p. 114-116.

${ }^{92}$ El documento está firmado en la Alhambra de Granada, a 6 de julio de 1484. Es un traslado hecho a fines del siglo XVI. ROJAS GABRIEL, M.: "Consideraciones sobre la vida en la frontera de Jerez durante el siglo XV", Actas de las II Jornadas de Historia de Jerez (Jerez medieval), Jerez, 1989, p. 34.

${ }^{93}$ GONZÁLEZ JIMÉNEZ, M.: "La frontera entre Andalucía y Granada. Realidades bélicas, socioeconómicas y culturales", LADERO QUESADA, M.A. (Coord.), La incorporación de Granada a la Corona de Castilla, Granada, 1993, p. 125; ROJAS GABRIEL, M.: La frontera del reino de Sevilla ...., p. 233, nota 180 .

${ }^{94}$ Documento original publicado en GARCÍA FERNÁNDEZ, M.: "La alfaquequería mayor de Castilla en Andalucía a fines de la Edad Media. Los alfaqueques reales", LÓPEZ de COCA CASTAÑER, J.E. (Ed.): Estudios sobre Málaga y el Reino de Granada en el V Centenario de la Conquista, Málaga, 1987, p. 52-54. Hay una copia en A.G.S. Registro General del Sello, junio 1514, sin foliar. 
determinado de cautivos por ciertas cuantías, no lo hacen e inflan el número de presos liberados con individuos que se hacen pasar por ellos en la frontera andaluza. Dice así:

“ $\{.$. algunas personas se an convenido con las personas que an tenido cargo de sacar los dichos cautivos, o con alguno dellos, para que le saquen algun numero de cautivos, e que en la provinçia del Andaluzía ay personas que tienen las barbas creçidas para esto, y que las tales personas que se obligaron de fazer la tal redençion sacan çierto número de cautivos e que juntavan con ellos otros tantos de las barbas creçidas e que con ellos enchan el número de los cativos que se obligaron a sacar y que desta manera llevan robada la mitad del dinero que reçibían para haser la dicha redençion $\{\ldots]$.

A pesar de las limitaciones arriba mencionadas, los alfaqueques estaban por encima de la hostilidad fronteriza y gozaban de algo similar a la inmunidad diplomática. Diego Ruiz, alfaqueque de Marchena, testigo en una "probanza" sobre la pérdida de Zahara a fines de 1481, declara que aquel año tuvo la oportunidad de ver a caballeros moros entrar en tierra de cristianos y de toparse en otras ocasiones con cuadrillas de almogávares rondeños sin que nada le sucediera ${ }^{95}$.

Esa "inmunidad" les permitía actuar como embajadores, mercaderes y espías De su actividad diplomática hay suficientes testimonios en las crónicas. En cuanto a su participación en el comercio, era inevitable pues los granadinos pedían a veces un rescate en mercancías. En los Milagros de Santo Domingo ya se habla de tejidos ingleses y flamencos, aceite, sal y cabezas de ganado. Los exeas mencionados en los fueros de Iznatoraf, Baeza y Úbeda, eran a menudo comerciantes de ganado y liberaban cautivos cobrando por su gestión el $12 \%$ del valor del rescate si se hacía en metálico, y un maravedí si se le intercambiaba por un moro ${ }^{96}$. En las Cortes de Madrid (1329) el rey Alfonso XI eximió del pago de impuestos a quienes llevaban cabezas de ganado a Granada para rescate, porque "non salen de catiuos muchos que saldrían" 97. Las referencias al ganado ovino abundan en los Milagros de Guadalupe: el amo de Juan de Teruel pide 200 ovejas y un paño de buriel; en el caso de Gonzalo de Córdoba, son 500 las ovejas exigidas y como el plazo asignado transcurre sin que pueda pagar, su dueño le pide el doble o que se torne musulmán ${ }^{98}$. García Quiñones, vecino de Lorca, entrega por su rescate 30 piezas de paño y 7 carneros ${ }^{99}$.

La crónica del condestable don Miguel Lucas de Iranzo nos ofrece un buen ejemplo del comportamiento peculiar de algunos alfaqueques. A fines de 1463 había una treintena de cautivos cristianos en la localidad de Montefrío. De noche dormían en una mazmorra y de día los moros sacaban "los que avien menester para servirse dellos". Como la mayoría de los moros trabajaba en el campo durante el día, los pri-

95 Añade que, estando en Ronda, oyó decir por donde se había de escalar Zahara. ROJAS GABRIEL, M. :ob. cit., p. 232.

${ }^{96}$ ARGENTE del CASTILLO, C.: "ob. cit., p. 221.

97 Cf. Cortes de Castilla y León, I, Madrid, 1861, p. 428.

98 Según Manuel Rojas, fueron 800 ovejas en el caso de Gonzalo de Córdoba. Las 500 corresponden a Bartolomé de Escobar, esclavo de Mahomad de Granada, quien le pide el doble o que se convierta. ROJAS GABRIEL, M.: ob. cit., p. 226-227.

99 VEAS ARTESEROS, F.A. y JIMÉNEZ ALCÁZAR, J.F.: “ob. cit”., p. 232-233. 
sioneros urdieron un plan para apoderarse de la fortaleza, con la ayuda de un cautivo anciano que dormía en casa de su dueña. Llegado el momento, éste les echaría una escala para que pudieran salir de la mazmorra, tomar el castillo "e çerrar las puertas, e armarse, e facer sus señales a quien les ouiese de acorrer". Así lo hicieron saber a un alfaqueque para que entrase en contacto con el Condestable y pidiera su ayuda. Tras varias idas y venidas del mentado alfaqueque se prepara el ardid y, la víspera del día fijado, los cautivos se desherraron dentro de la mazmorra y se confesaron unos a otros. A la mañana siguiente,

“acaeçió que un moro llegó enzima de la mazmorra e llamó un moço catiuo suyo christiano, de hedad de honze o doce años, que estaua con los otros, que lo avie menester. E quando salió, los otros cristianos, por ser moço e de poco esfuerço, reçelándose dél, rogárosle mucho que no dixiese nada a los moros. E luego como salió, con poco seso o con miedo, dixo a su señor cómo los cristianos estaban todos desferrados en la maçmorra, e que se avían abraçado e besado, e que ese día avían de dar el alcaçaba a los cristianos (...)" ${ }^{\prime 100}$.

\subsection{LA ALFAQUEQUERÍA MAYOR DE CASTILLA}

Enrique II incluye la figura del alfaqueque mayor "entre los grandes ofiçios syn jurisdicción de la casa del rey", según consta en el Ordenamiento de Toro (1369) y en las actas de las Cortes celebradas en la misma ciudad, en las que se menciona por vez primera la "alfaquequería mayor de tierra de moros". Pero no hay constancia de ningún titular del oficio hasta 1410: Diego Fernández de Córdoba aparece como tal en las negociaciones y acuerdos suscritos con Granada aquel año ${ }^{101}$. Le sucede Jerónimo López de Saldaña, tesorero del rey y caballero veinticuatro de Sevilla, que muere en 1438. En julio del año siguiente el oficio pasa de por vida a Juan de Saavedra, alcaide de Castellar ${ }^{102}$.

De 1439 en adelante el cargo de alfaqueques mayores lo ostentarán miembros de este linaje sevillano. Los diferentes nombramientos reales especifican los derechos y deberes de quienes eran los únicos que podían organizar el rescate de cautivos en toda la frontera, de Lorca a Tarifa. En la práctica delegaban sus funciones en unos alfaqueques menores mediante arriendo al mejor postor por un año o seis meses, según muestran ciertos documentos notariales de Antequera fechados en 1486. De este modo, el oficio de alfaqueque sería desempeñado por gente que sólo quería resarcirse de la inversión realizada, haciendo caso omiso de lo dispuesto en la Partida $\mathrm{II}^{103}$.

A decir verdad, no hay noticias de alfaqueques nombrados por los Saavedra fuera del reino de Sevilla, área de influencia de este linaje. En el reino de Córdoba ni siquiera hay datos sobre los alfaqueques en la documentación conservada: apenas

\footnotetext{
${ }^{100}$ Cf. Hechos del condestable don Miguel Lucas de Iranzo, p. 103-109.

101 TORRES FONTES, J.: “Los alfaqueques...”, p. 104-105.

${ }^{102}$ GARCÍA FERNÁNDEZ, M.: “ob. cit.”, p. 39 y ss.
}

103 La multiplicidad de alfaqueques menores justifica la existencia de un "alcalde de alfaqueques", oficio desempeñado por Pero Sánchez Tristán y, a partir de 1470, por su hermano Gonzalo; en ambos casos por recomendación de Fernan Arias de Saavedra, entonces alfaqueque mayor. Ver el nombramiento firmado por Enrique IV en Madrid, el 17 de mayo de 1470, en A.M.S. Actas Capitulares 1470, mayo-agosto, f. 44. 
se les ve actuar directamente y casi no se conocen sus nombres ${ }^{104}$. La alfaquequería y exea de Quesada estuvo en manos de Gonzalo Carrillo y de su hijo Hernando Carrillo, que falleció mediada la década de los ochenta ${ }^{105}$. El 7 de agosto de 1476 un criado de Gonzalo Carrillo entregó al concejo de Jaén el traslado de una carta de los Reyes Católicos aceptándolo como alfaqueque "segund e en la manera que fasta aquí lo ha tenido"106. El 11 de septiembre de 1480 Martín del Cuerpo y Pedro Sánchez presentan cartas de arrendamiento del oficio de alfaqueque otorgadas por Gonzalo Carrillo "segund las ordenanças del alhaquequería", que son aprobadas por los regidores gienenses ${ }^{107}$. En el reino de Murcia, como las Partidas distinguían entre alfaqueques de designación real y concejil, en 1460 Enrique IV autorizó a la ciudad de Lorca a ejercer su facultad en dicho sentido frente al adelantado Pero Fajardo, que había intentado impedirlo. ${ }^{108}$. Después de la conquista de Granada se "restaura" la alfaquequería mayor a fin de poner orden en la redención de los cautivos llevados a Berbería. En una pesquisa previa saldrá a relucir que los Saavedra habían carecido de competencias fuera del área sevillana ${ }^{109}$.

\subsection{LAS ÓRDENES RELIGIOSAS}

Estamos al tanto de la actividad desplegada por la orden de $\mathrm{N}^{\mathrm{a}}$ Señora de la Merced en la Corona de Aragón y en lo que toca a los cautivos llevados a Granada o al norte de África. Según John Brodman las expediciones se organizaban anualmente en el capítulo de la orden. Los frailes, que viajaban por parejas, habían de reunir dos condiciones básicas: ser templados, evitando excesos de alimentos y bebida, y sabios, versados en rescates, experimentados. Llevaban consigo un guidaticum que aseguraba su integridad física y les eximía del pago de impuestos. De esta manera liberarían algunas decenas de cautivos, pero no centenares según la leyenda. Si bien los frailes no cobraban por su trabajo -al revés que otros redentores-, los excautivos quedaban obligados a pedir limosna por cuenta de la Orden durante 6 meses ${ }^{110}$.

${ }^{104}$ Se menciona, por ejemplo, a un alfaqueque mudéjar natural de Palma del Río. CABRERA MUÑOZ, E.: "ob. cit.", 158.

${ }^{105}$ Así consta en una petición de Juan Carrillo, hijo y nieto de los citados, a la reina Isabel: “ $\lceil\ldots$. J después que la tierra se ganó a los moros dizen que los tales derechos non se pagan, por lo qual sy vuestra alteza esta merçed non me permutare en otra parte yo sería perdido, porque lo poco que mi padre me dexo, todo u la mayor parte he vendido para servir a vuestra alteza, asy por estos caminos como en las guerras pasadas después de la de Baça". A.G.S. Cámara de Castilla. Personas, leg. 6, s. f.

106 A.M.J. Actas Capitulares 1476, f. 184 r., según GARRIDO AGUILERA, J.C.: “ob. cit.”, p. 169.

107 En detrimento de Juan de Madrid, a quien se prohíbe que ejerza el oficio de alfaquequería a pesar de haber presentado otra carta de arrendamiento de Gonzalo Carrillo. A.M.J. Actas Capitulares 1480, f. 74 r., Ibidem, p. 171. El alforjero Johan Sevillano, vecino de Jaén, se obliga como fiador de los mentados alfaqueques: responderá por ellos en el caso de que se vayan con parte de los rescates, no cumplan con sus obligaciones o perdiesen algo. Ibidem.

${ }^{108}$ Según la provisión expedida en Valladolid el 3 de septiembre de 1460 a favor de un alfaqueque concejil. TORRES FONTES, J.: ob. cit., p. 113; A.M.L. Libro de Privilegios II, f. 27 r.-28 v. Lo mencionan VEAS ARTESEROS, F.A. y JIMÉNEZ ALCÁZAR, J.F.: “ob. cit.”, p. 230, nota 3.

${ }^{109}$ LÓPEZ de COCA CASTAÑER, J.E.: "Andalucía y el norte de África”, p. 277-280.

${ }^{110}$ BRODMAN, John W.: Ransoming Cautives in Crusader Spain. The Order of Merced on the ChristianIslamic Frontier, Filadelfia, 1986, p.108-116 en particular. 
Había casas-conventos de la Merced y de la Santísima Trinidad en Murcia, Lorca, Córdoba, Sevilla y Jerez, que recibían donaciones y limosnas de los poderosos. En 1394, por ejemplo, D. Alvar Pérez de Guzmán, señor de Olvera, legaba en su testamento "a las órdenes de la Trenidat e de Santa María de la Merçet de Sevilla, por ayuda de sacar catyvos, a cada una, una dobla de oro"111. Por su parte los mercedarios de Córdoba organizaban de vez en cuando predicaciones destinadas a recoger fondos para los rescates ${ }^{12}$. En cambio, no hay señales de la actividad redentora de ambas órdenes en el reino de Jaén ${ }^{113}$.

Las limosnas llegaban de toda Castilla. En 1436 fray Pedro de Castril de Peones, ministro de la Trinidad de Burgos, recibe 3.000 maravedíes de Gonzalo González, clérigo de Aguilar de Campoo, como cabeçalero del vecino Ruy González, para "sacar un captivo de tierra de moros". El ministro se compromete a liberarlo en el plazo de año y medio, so pena de pagar el doble de esa suma, para lo cual obliga los bienes del monasterio. Una vez traído a la villa de Aguilar, lo dejará "libre e esento para que se vaya donde quisiere, so la dicha pena"114.

En la segunda mitad del siglo XV parejas de frailes trinitarios procedentes de Arévalo y de Burgos se desplazaban hasta Córdoba para organizar más fácilmente la distribución de fondos. Pero las cantidades de dinero que entregaban, ante notario, a las familias que tenían parientes cautivos en Granada eran, más bien, ayudas para completar el precio del rescate. De no lograrse éste en un plazo de 20 a 30 días, había que devolver a la orden el dinero prestado. Según parece, los frailes no iban a territorio granadino en busca del cautivo. Esta tarea competía a otras personas, a menudo familiares del propio cautivo ${ }^{115}$.

Si el rescate se consumaba, el individuo liberado quedaba en deuda con la orden. En 1452, estando en Sevilla Fr. Juan Gómez, provincial de la orden de la Trinidad en Castilla, entregaba a Miguel de Carmona, vecino de Carmona, 20 doblas de oro castellanas para rescatar a su nieto "Juanico". El susodicho se compromete a que el tal "Juanico" servirá a los frailes de la Orden durante un año y un día; en el caso de que no lo hiciera habría de devolver la suma recibida ${ }^{116}$.

Mención aparte merecen los monjes jerónimos. A raíz del secuestro de la población de Cieza, en 1447, el prior de Guadalupe, frey Gonzalo de Madrid, escribió una carta al rey Juan II y a don Alvaro de Luna,

"que era todo el gobierno del reino, culpándoles del mal recado que tenían en las fronteras, y cuán fea cosa era ver llevar cada día gente cautiva a poblar las mazmorras

${ }^{111}$ Testamento otorgado en Sevilla, el 11 de junio de 1394. ROJAS GABRIEL, M.: ob. cit., p. 227, nota 165 .

112 CABRERA MUÑOZ, E.: “ob. cit., 156.

113 ARGENTE del CASTILLO, C.: "ob. cit., p. 217.

114 Compromiso asumido ante notario en Burgos, a 28 de junio de 1436. SERRANO o.s.b., Luciano: Los conversos D. Pablo de Santa María y D. Alfonso de Cartagena, Madrid, 1942, doc. X del apéndice.

${ }^{115}$ CABRERA MUÑOZ, E.: “ob. cit.”,157.

116 BONO, J. y UNGUETI-BONO, C.: Los protocolos sevillanos de la época del Descubrimiento, Sevilla, 1986, p. 81. No es una novedad: en 1290 Alfonso III de Aragón permitía a la orden de la Merced que dispusiera de la ayuda temporal de cautivos rescatados por sus frailes. RAMOS LOSCERTALES, J.M.: ob. cit., p. 169 y ss. 
de Granada y a robar a Castilla con los rescates, y ver tanto cristiano esclavos miserables de los infieles moros, suplicándole también se compadeciese de aquel afligido pueblo que habían saqueado y cautivado y mandase proveer en su rescate".

El monarca y don Álvaro hicieron poco caso de la carta del prior, quien, incapaz de atender las peticiones de ayuda que recibía, persuadió a los miembros de su comunidad para vender las lámparas de plata que ardían delante de la Virgen, salvo una, en socorro de los desgraciados. Obtuvo cien marcos de plata de ellas y envió a dos religiosos a tierras granadinas, que rescataron a más de cincuenta cautivos ${ }^{117}$. Por cierto, una carta de Juan II (9/junio/1450) les advierte que obligadamente han de llevar "pendón propio y trompeta cuando se sacaran cautivos"

\section{LA APOSTASÍA}

El riesgo de que los prisioneros renegaran de su fe está relacionado en parte con la duración del cautiverio. Los protocolos notariales cordobeses muestran que sólo el $14 \%$ de los rescates se resuelven en menos de un año; un 36\% tardaban entre uno y dos años en volver a casa; otro $14 \%$ entre 2 y 5 años, y 36\%, más de 5 años. También lo está con la indefensión en que quedaban mujeres y niños al ser los varones adultos quienes se rescataban mayoritariamente: era preferible recuperarlos a ellos y evitar, de ese modo, que sus familias quedaran desasistidas ${ }^{119}$.

La apostasía fue frecuente entre los niños de corta edad. En la pesquisa sobre los elches residentes en Granada y su término (1499-1500), se recoge el testimonio de la viuda Hirtil, natural de Villacarrillo:

"e no sabe quien fue su padre ni su madre salvo que fue trayda chequita cabptiva a esta çibdad e se llamava Teresa y estuvo christiana obra de un mes o dos y luego se tornó mora e ha bevido en la ley de Mahoma hasta agora, que será de hedad de 55 años poco más o menos".

No menos elocuente es la declaración de Reduan, vecino de la alquería de Otura:

"dixo que le habían traydo a esta çibdad de Granada seyendo de IX meses, segund su madre le dixo, que cree que es bautizado pero que no se acuerda como le llamaron pero que cree que se llamó Juan, e que asy se quiere agora llamar, e que ha bivido como moro hasta agora".

117 SIGÜENZA J. de: Historia de la orden de San Jerónimo, ed. actualizada y corregida de A. Wervaga Prieto, estudio preliminar F. Campos y Fernández de Sevilla, Madrid, 2000, t. 2, $3^{\mathrm{a}}$ parte, libro segundo, cap. VII, p. 225-226; TORRES FONTES, J.: "La frontera de Granada en el siglo XV”, p. 203- 204.

118 TORRES FONTES, J.:“Los alfaqueques en la frontera de Granada”, p. 114.

119 CABRERA MUÑOZ, E.: “ob. cit.”, 144-145. Un caso de cautiverio de 13 años de duración en la frontera entre Vera y Lorca. GARCÍA ANTÓN, J.: “ob. cit.”, I, p. 557. 
O el caso de Ali, nacido en Çehegin, que "fuera ydo por rehenes de un su hermano, de hedad de çinco o seys años, e que avrá XXXV años poco más o menos que ha estado e bivido como moro"120.

En la relación de un milagro atribuido a la Virgen de Guadalupe se menciona la existencia de una norma consuetudinaria referente a los menores de edad. Un chico de 10 años, Francisco, hijo del sevillano Rodrigo de Berrio, había sido apresado y vendido al arráez de Málaga, que lo convierte a la fe islámica. Dejando como rehén a otro hijo suyo, el padre consiguió del alcaide de Jimena, que mantenía buenas relaciones con el malagueño, una carta de "ruego" en la que pedía:

"que le guardase su justicia segund el fuero e ley de la frontera, en la qual se contiene que si algund moço christiano de quinze annos abaxo se tornase, o le tornase, moro, e viniendo su padre e madre demandándolo, son tenudos los moros de ge lo poner delante. E si el moço dize que se quiere tornar a la fe de los christianos dan gelo por su rescate. E si el moço dixere que quiere estar e perseverar en la seta de Mahomad non ge lo darán en manera alguna"

El mocito no quiere y niega, además, que Rodrigo sea su padre. Éste marchó a Córdoba en busca de una carta de recomendación "del señor don Alfonso, cuya es la casa de Aguilar, para el alcaide de Málaga", quien consiente en recibirlo por deferencia al noble cordobés. Pero Francisco insiste en no volver. Finalmente, tras una dramática entrevista con la madre, la Virgen toma cartas en el asunto: el chico reconoce a sus padres, retorna su hogar y al seno de la Iglesia ${ }^{121}$.

En la reunión del cabildo municipal de Jaén celebrada el 28/agosto/1479, se lee una carta del alcaide moro de Colomera que dice:

"Señores, reçebimos los dos moros nuestros que vosotros nos enbiastes, e luego vos enbiamos los tres cristianos vuestros; e sabed, honrrado conçejo e caualleros, quel un moço se tornó moro, e nosotros ovimos mucho pesar dello, e le deximos que fuese con sus conpañeros e no quiso. Mandad que venga su madre e parientes aquí a Colomera, e trabajen con el moço para que se valla con ellos, y nosotros lo dexaremos ir; y vengan los que vernán seguros. E somos prestos en todas cosas, honrados cavalleros, de facer lo que mandáredes" 122 .

Ese mismo año las autoridades gienenses se habían interesado por un mozo que estaba en Colomera por rehén de un tal Prada y que, según decían, había abjurado de su fe. La respuesta granadina fue:

${ }^{120}$ LADERO QUESADA, Miguel Ángel: "Nóminas de conversos granadinos (1499-1500”, LÓPEZ de COCA CASTAÑER, José Enrique (Ed.): Estudios sobre Málaga y el reino de Granada en el $V$ Centenario de la Conquista, Málaga, 1987, p.304- 305.

121 Según GONZÁLEZ JIMÉNEZ, M.: "La frontera entre Andalucía y Granada”, p. 128-129; ROJAS GABRIEL, M.: ob. cit., p. 216-217.

${ }^{122}$ CARRIAZO y ARROQUIA, J. de M.: “ob. cit.”, 30. 
“(...) este moço fue entregado al jurado Martín de Espinosa e a su padre, e a otros muchos cristianos, y lo tovieron apartadamente y hablaron con él sin estar los moros presentes; y todavía dixo que era moro. El qual ya es onbre" ${ }^{123}$.

También hubo conversiones voluntarias entre los cautivos adultos. El lorquino Gaytan, apresado por moros de Huércal, es conducido a Vera para su venta. Una vez allí, expresó al cadí veratense su intención de ser musulmán, tras lo cual fue puesto en libertad. Dos chicas cristianas, apresadas, reniegan y contraen sendos matrimonios con musulmanes. La madre de otra quiso rescatarla y renegó, quedándose en Vera ${ }^{124}$. A tener en cuenta, no obstante, que un cautivo cristiano no recobraba la libertad por el simple hecho de manifestar su deseo de convertirse a la fe del contrario: también debía pagar el rescate a su dueño. Del mozo que echó a perder el ardid urdido por los cautivos de Montefrío el cronista Escavias escribe: "Y en fin, los moros el catiuo que les descubrió este fecho tornáronlo moro, e pagaron a su señor por él su rescate"125.

Para un cristiano que deseaba convertirse a la fe de sus captores, la mejor manera de convencerlos acerca de la sinceridad de su propósito era aceptar que lo circuncidaran o. de ser necesario, hacerlo por sí mismo. En el cabildo municipal de Jaén celebrado el 9 de agosto de 1479 comparece Fernando, hijo del vecino Martín López de Castro, y declara que estando cautivo en Arenas hará un año y medio, los del lugar apresaron a un muchacho:

"E que luego tomaron al dicho moço e lo sobieron al alcaçaba ques en el dicho castillo de Arenas, e le echaron un fierro al pie, e lo tovieron secreto; fasta tanto que puede aver quatro meses quel dicho moço se cortó su natura e dixo que era moro, e lo tornaron moro. E que antes que lo tornasen moro, este testigo vido cómo el dicho moço se salió fuyendo por la puerta falsa, e lo alcançaron los de Arenas çerca de Montexícar, que se iva a tornar moro, e lo bolvieron, e no le querían quitar el fierro; e porque no ge lo quitaron, se cortó él mismo la natura; e lo tornaron moro, e es moro, e lo tienen en Arenas" $" 126$.

En teoría, un converso recién circuncidado no podía ser devuelto a los suyos. De ahí la sorpresa que manifiesta D. Lorenzo Suárez deFigueroa, maestre de Santiago, en una carta enviada al rey Enrique III (Guadalcanal, 24/mayo/1406) poniéndole al corriente del inicio de unas conversaciones de paz con Granada. El emir había dado el primer paso al devolver a un muchacho de Estepa "que avían furtado sus moros", pese a "que ya avían tornado moro el dicho moço e era tajado"127.

El jurado Martín de Espinosa también se interesa por una cristiana de Huelma apresada por los de Cambil, que "se tornó mora; y es cristiana". Es posible que la contestación que recibió en este caso le pillara por sorpresa:

\footnotetext{
123 CARRIAZO y ARROQUIA, J. de M.: “ob. cit.”, 31.

124 GARCÍA ANTON, J.: “ob. cit.”, I, p. 552-553.

125 Cf. Hechos del Condestable don Miguel Lucas de Iranzo, p. 109.

126 CARRIAZO y ARROQUIA, J. de M.: “ob. cit.”, 29.

${ }^{127}$ Lo trajo un emisario granadino a escondidas y, con él, una carta para el rey de Castilla. El maestre insiste en "que fue una maravilla quererle echar seyendo ya moro". A.G.S. Estado leg.1-1", f.105.
} 


\begin{abstract}
"Respóndese que esta que dice ser cristiana no es de la calidad de los que agora se demandan, porque ésta vino de su buena voluntad como es notorio e verdad; e después de estar en esta çibdad de Granada e ser mora, en este medio tienpo vino Martin de Lara, alhaqueque, e estovo e habló con ella departadamente y ella quedó por mora, como lo era. Y después ella fue casada, e estovo grand tienpo por mano e mandado del alcalde mayor de los moros; la qual huyó de casa de su marido con un enamorado mudéjar que tenía, y fue tomada y presa. E mirando lo susodicho ser así, como es verdad y pasó, ya veis si es razón demandar la tal muger como ésta"128.
\end{abstract}

\title{
5. LOS CAUTIVOS GRANADINOS
}

Hay pocos testimonios acerca de los cautivos granadinos en Murcia y Andalucía. En el primer caso se trataba de esclavos domésticos que gozaban de cierta libertad de movimientos: las aljamas mudéjares respondían económicamente por los cautivos en caso de huída. Por eso, no puede establecerse una semejanza o paralelismo entre el cristiano cautivo en Granada y el moro en servidumbre del reino de Murcia ${ }^{129}$.

En Andalucía no existía nada parecido al "corral de Granada", donde solían guardarse los cautivos cristianos pertenecientes al emir. Pero la suerte de un cautivo en poder de un particular recuerda mucho a la de su homólogo cristiano, retenido en territorio granadino. Trabajaran en el campo o en la ciudad, los cautivos musulmanes llevaban grilletes en los pies hasta que recuperaban la libertad. En 1468 Alonso el Gordo, alfaqueque de Jaén, pidió licencia al concejo pues tenía "çiertos moros deserrados e otras mercadurías para leuar al reyno de Granada, e traer de allá algunos cristianos" $" 130$.

El poeta 'Abd al-Karim al-Qaysí de Baza, que estuvo preso en Úbeda circa 1355, escribió unos versos recordando su estancia en la "tierra de la oscuridad". Respecto a sus condiciones de vida, señala que dormía en un lugar estrecho con las manos aherrojadas. Y añade:

"Atardezco y madrugo esclavo a disposición/ de los devotos de los ídolos y de la cruz./ Si no trabajo en la labra/ me ocupo de la demolición de los edificios;/ y en el día de mi descanso, mi profesión es barrendero,/ y luego riego la tierra a menudo./ Y el lavado de la suciedad de los perros es mi oficio,/ en la mayoría de los días/. Sus vestidos se lavan con mis propias manos,/ mientras que los míos están, todo el tiempo, ensuciados"131.

La referencia al lavado de los perros no hay que interpretarla en sentido literal: los perros son los cristianos y el se ve forzado a lavar sus ropas.

128 Carriazo califica a esta renegada de "mujer tan resuelta como enamoradiza".Cf. "Relaciones fronterizas...", 31 .

129 Según TORRES FONTES, J.: "La frontera de Granada en el siglo XV”, p. 200-201.

${ }^{130}$ Cf. Hechos del Condestable don Miguel Lucas de Iranzo, p. 382.

131 BEN DRISS, Abdelghaffar: "Los cautivos entre Granada y Castilla en el siglo XV según las fuentes árabes", Actas del Congreso "La Frontera Oriental nazari como sujeto histórico (s. XIII-XVI)”, Almería, 1997, p. 304-310 en particular. 


\subsection{FINANCIACIÓN DE LOS RESCATES. LOS BIENES HÁBICES}

Se sabe poco de los cautivos granadinos que se fugaban y conseguían cruzar la frontera. Según la pesquisa hecha en la villa de Zahara acerca de su pérdida a fines de 1481, aquel año escaparon dos moros del castillo, a través de un portillo abierto en el paramento de la muralla, bajando luego por la peña tajada con ayuda de una soga. Un testigo declara que veinte años antes, "se fue una esclava con una niña a cuestas, y se dezía que se descolgó por allí con una soga a boca de noche, antes que las velas començasen a velar (...)"132.

Hemos visto que en las negociaciones diplomáticas entre Castilla y Granada hubo siempre acuerdo en respetar el derecho de fuga de los cautivos de una y otra parte. Pero ese acuerdo se circunscribía a la frontera terrestre. Una fetua de Ibn Siray (m. 1444) declara que no hay obligación de devolver a unos esclavos musulmanes que se habían evadido de un navío cristiano surto en un puerto granadino y, tampoco, de pagar un rescate por ellos ${ }^{133}$.

La mayoría de los cautivos recobraban la libertad tras haber pagado el rescate pedido por sus dueños, o mediante el trueque con un prisionero del bando contrario. 'Abd al-Karim al-Qaysí da cuenta de las exigencias de su amo en los versos siguientes:

"Se burla cuando me dice:/ ¿cuánto pagarás para liberarte de mi servicio y de mi dominación?/ Me callo, mientras que mi corazón/ oculta grandes penas y calamidades./ E insiste hasta que le digo:/ ¿cuánto quieres?, pero no seas grosero./ Y me pide siempre mil de las amarillas/ y veinte cautivos como precio mínimo/. Y juro que no dispongo ni de su décima parte" ${ }^{\prime 134}$.

El faquí Muhammad b. Ahmad al-Dawsi (1269-1337), versado en cuestiones notariales, exhortaba a sus conciudadanos a recaudar fondos para el rescate de cautivos y, según cuenta Ibn al-Jatib, gracias a sus colectas y a su habilidad en la mediación, liberó a grandes cantidades de ellos ${ }^{135}$.

También tenían importancia las mandas testamentarias y otros legados piadosos. En un testamento fechado a 17 de marzo de 1487, se donan 13 dinares para rescatar a un cautivo ${ }^{136}$. Algunas fetuas granadinas plantean una casuística interesante respecto a estos legados. Según el jurista Ibn Lubb (m. 1381), el legado destinado al rescate de cautivos sin fortuna del lugar donde reside el testador puede ser utilizado, si sobrara, para rescatar a un cautivo de la localidad más próxima. Otro dictamen del mismo faquí concierne a una cautiva granadina que había concertado su rescate en una cantidad determinada. Un muecín pide dinero por ella y lo deposita en manos de un

132 ROJAS GABRIEL, M.: ob. cit., p. 220 y nota 146.

133 LAGARDÈRE, V. : Histoire et societé en Occident musulman au Moyen Âge. Analyse du "Mi yar » d'al-Wansarisi, Madrid, 1995, p. 58.

134 Abdelghaffar BEN DRISS, supra $\mathrm{n}^{\circ} 131$.

135 ARIÉ, Rachel : L'Espagne musulmane au temps des Nasrides (1232-1492), Paris, 1973, p. 326 ; CARMONA GONZÁLEZ, Alfonso: "La frontera : doctrina islámica e instituciones nazaríes", Actas del Congreso "La Frontera Oriental nazari como sujeto histórico (s. XIII-XVI)”, Almería, 1997, p. 56.

136 SECO de LUCENA PAREDES, Luis: Documentos arábigo-granadinos, Madrid, 1961, doc. 58, p. 101 ; trad. española en p. 109. 
encargado (amin) a la espera de que la mujer pueda completar la suma. Ésta recorre el país pidiendo limosna y vuelve con el dinero íntegro de su rescate. Ahora reclama al amin el dinero recogido por caridad y cuya propiedad no le ha sido reconocida en un acta. Ibn Lubb opina que el encargado debe devolver lo que ella no ha necesitado ${ }^{137}$.

Ignoro si la mujer en cuestión había dejado algún rehén en tierra castellana. Pero esta práctica, muy extendida entre los cristianos, no era ajena a la experiencia granadina. Encontramos un antecedente en la fetua del faquí cordobés Ibn Sulayman (m. 914) sobre un cautivo muslime, preso en territorio enemigo hasta que pagase 100 dinares por su rescate. Deja a un hijo como rehén y vuelve a tierra del Islam para vender sus bienes y reunir la suma necesaria para redimirse ${ }^{138}$. Las fuentes castellanas dan fe de la pervivencia de esta práctica en la Granada nazarí, según he indicado antes ${ }^{139}$.

Había particulares que instituían sumas diversas de dinero como bienes hábices para la redención de cautivos. Dos fetuas de época nazarí se ocupan de la responsabilidad de quienes administraban ese dinero. Un requisito fundamental de tales legados fue, al parecer, que los cautivos rescatados se comprometieran a devolver la cantidad que se había pagado por ellos y, de esta manera, asegurar la perennidad del habiz. En la primera fetua, al-Saraqustí afirma que los prisioneros no serán exonerados por menos dinero del que se pagó por ellos, aunque el propio administrador lo haya hecho, ya que éste no puede disponer de la propiedad ajena. El cautivo rescatado que afirme haber devuelto lo que se pagó por él, deberá probarlo. La fetua de Ibn `Allaq dice que el administrador del legado ha de confiar el dinero a cambio de garantías y prendas que aseguren su devolución. Tampoco debe dedicarlo a otros fines distintos al estipulado aunque actúe de buena $\mathrm{fe}^{140}$.

Fuentes castellanas posteriores a la caída del emirato contienen datos sobre bienes rústicos instituidos como hábices para redimir cautivos. En las alquerías de la Vega granadina los bienes cuyas rentas sirven a este propósito son los más numerosos: alrededor de un $59 \%$ del tota ${ }^{141}$. En la comarca de la Alpujarra un inventario de hábices hecho a principios del siglo XVI revela la existencia de un "Arca de los cautivos". A cuenta del mismo había 472'25 marjales de tierra, equivalentes a unas 24 hectáreas, y muchos árboles: alrededor de 500 morales, 65 olivos, 3 castaños, un nogal y una higuera. La rentabilidad de los morales era tal - sus hojas alimentaban a los gusanos productores de seda--, que el arca incluía 16 matas de moral, 2 árboles cortados y un tronco. Además, tanto en Yegen, alquería de la ta a de Jubiles, como en otros lugares de las ta as de Dalías y Berja, se adjudicaban horas de agua durante el día o la noche en ciertas fechas del año ${ }^{142}$.

${ }^{137}$ LAGARDÈRE, V.: ob. cit., p. 421;267-268.

138 Ibidem, p. 54.

139 GARCÍA ANTON, J.: “ob. cit.”, I,p. 557-558 .

${ }^{140}$ GARCÍA SAN JUAN, Alejandro: Hasta que Dios herede la tierra. Los bienes hábices en al-Andalus (siglos X-XV), Huelva, 2002, p. 189-190. Extractos de las fetuas comentadas, en LAGARDÈRE, V.: ob. cit., p. 267-268 ; 283-284.

${ }^{141}$ HERNÁNDEZ BENITO, Pedro: La Vega de Granada a fines de la Edad Media según las rentas de los hábices, Granada, 1999, passim. Según el cálculo hecho por García San Juan .

${ }_{142}$ Los datos proceden de A.G.S. Contaduría Mayor de Cuentas, leg. 131. 
El canje o trueque de cautivos era la otra opción a la que recurrieron los granadinos para liberar a los suyos. La importancia que le daban a esta forma de liberación se pone de manifiesto en el curso de las negociaciones con Castilla celebradas en 14381439. El emir Muhammad IX pidió a Juan II que renunciara a exigir la entrega de todos los cautivos cristianos que había en Granada y su reino:

"questo es cosa fuerte et cosa que non puede ser, et non podría ninguno faserlo, por cabsa que los moros cautivos omes e mugeres muchachos e demás, que están en el regno de Castilla, e los cautivos que están en el regno de Granada, están en poder de los parientes de aquellos questan en el regno de Castilla, por destroques, segund uso e costunbre; e cómo puede ser en manera de las del mundo, que tomen cabtivo christiano de mano de quien lo tiene, para sacar su hermano o su fijo o su pariente"143.

Los cautivos granadinos estantes en territorio murciano contaron con la solidaridad de las aljamas mudéjares a la hora de obtener fondos para redimirse. En una carta de Juan II (Madrigal, 2/agosto/1438) al concejo de Murcia, leemos que "muchos moros catiuos, así del regno de Granada como de otros regnos de moros", se rescataban con sus dueños gracias a las fianzas que daban algunos mudéjares regnícolas. Esto permitía a los cautivos ir de aljama en aljama pidiendo limosna y socorro para sus rescates hasta que lograban reunir el dinero necesario. Pero existía el riesgo de que, una vez libres, volvieran para saltear en el país murciano, que ya conocían gracias a sus vagabundeos como mendicantes. Con el propósito de abolir esta costumbre, el monarca dispone que "sy alguno de los dichos moros catiuos se quisieren rescatar que trayan su rescate del dicho regno de Granada o de los otros regnos donde fueren naturales (...)"144. Al no cumplirse, la prohibición será confirmada en 1446 y 1459 por lo menos ${ }^{145}$.

\subsection{SOBRE LOS ALFAQUEQUES}

Aunque las actividades de los alfaqueques granadinos están mal documentadas parece que fueron más numerosos que sus homólogos cristianos, compartiendo con ellos la obligación de llevar pendones que los identificaran. En el cabildo celebrado en Jerez el 4/abril/1484 se asegura a un alfaqueque moro de Ronda, "para que él pueda ir e venir por los términos de esta çibdad, derechos los que van e vienen a esta çibdad, trayendo pendones según la costunbre de alfaqueques"146.

El alfaqueque cruzaba las lindes con su acompañante, provisto de un salvoconducto expedido por las autoridades del lado contrario ${ }^{147}$. Algunas fuentes árabes denun-

${ }^{143}$ La cursiva es mía. AMADOR de los RÍOS, J.: ob. cit., p. 85-86. Supra, no 71 y 72

144 Cf. Documentos de Juan II, ed. Juan Abellán Pérez, Murcia-Cádiz, 1984, doc. 200, p. 496-497.

145 Un posible precedente: la licencia otorgada por Juan I (Salamanca, 14/mayo/1381) a los dueños de cautivos moros en Murcia para venderlos en Aragón si aquellos no quieren redimirse o nadie los compra. SUÁREZ FERNÁNDEZ, Luis: Historia del reinado de Juan I de Castilla II: Registro documental (13711383), Madrid, 1982, doc. 243, p.367.

146 SANCHO de SOPRANIS, Hipólito: "Jerez y el reino de Granada a mediados del siglo XV”, Tamuda (Tetuán) II (1954) 305; GARCÍA FIGUERAS, T.: “ob. cit.”, p. 280.

147 Supra no 91 
cian las prácticas fraudulentas. En fecha imprecisa el muftí de Granada es consultado sobre un alfaqueque que fue a tierra de cristianos con moneda depreciada y estos se la tomaron dos por una. A su regreso con los cautivos, quiso que los familiares le reembolsaran lo que había pagado de más. Pero el muftí declara que no ha lugar dicho pago, pues el alfaqueque debía correr con el riesgo. La misma fetua acusa a otros rescatadores de comerciar con seda, adelantando dinero a cuenta de la seda que se esperaba recoger en la siguiente temporada, lo cual se consideraba usura ${ }^{148}$.

La depreciación de la moneda nazarí en el siglo XV hizo que los redentores musulmanes se vieran forzados a pagar los rescates de sus correligionarios con madejas de seda. Un documento notarial de 7/agosto/1486 recoge el compromiso de dos alfaqueques de la ta'a de Laujar, los cuales "garantizan con su hacienda y bajo su responsabilidad 5 libras y media de hilo de seda laujarí a dos cristianos, a cambio del rescate de Ahmad b. Ahmad al-Bastí en un plazo de 20 días"149. En la frontera con el reino de Murcia, los rescates de moros apresados por los vecinos de Lorca se pagaban en seda hilada en mazo, que se pesaba en la Fuente de la Higuera, el lugar habitual para los tratos de esta índole, o en seda y dinero. Sabemos de un vecino de Vélez Blanco que ofrecía siete libras y media de seda joyante por un muchacho preso en Lorca ${ }^{150}$.

A los alfaqueques doblados de comerciantes habría que añadir aquellos otros de conducta dudosa. La figura del alfaqueque espía sale a relucir en la discusión mantenida por el emir Muhammad IX el Izquierdo con el alcaide, o arráez, de Almería en 1419 , tras el fallido intento de arrebatar Ceuta a los portugueses. El nazarí quiere atacar la plaza de nuevo, animado por las noticias que traen los alfaqueques granadinos. Pero su consejero le recuerda que no puede mover un remo en sus dominios sin que se sepa en Tarifa, y lo mismo hace el emir con los cristianos, que no pueden tramar nada sin que él se entere antes ${ }^{151}$.

También hay que señalar la falta de escrúpulos en el desempeño de las tareas propias del oficio. Las fuentes castellanas denuncian esa carencia en el caso de "Hamete el Majo", un alfaqueque que solía acudir a Jaén en la segunda mitad de los años setenta del siglo $\mathrm{XV}^{152}$. El 13 de noviembre de 1479, el concejo gienense escribe al visir de Granada, "Abulcacin Venegas", para manifestarle que el mentado alfaqueque no es "honbre de verdad". Según el alfaqueque Martín de Lara, él y el granadino,

"guardando la fidelidad e verdad de sus ofiçios e trato, (...)han sido trujamanes e conpradores de çiertos moros que fueron levados a ese reyno e çibdad de Granada; de

148 LÓPEZ ORTIZ, José: “Fatuas granadinas de los siglos XIV y XV”, Al Andalus (Madrid-Granada) VI (1941) 94-95.

149 SECO de LUCENA, L.: ob. cit., doc. 57, p. 100; traducción española en p. 108.

${ }^{150}$ GARCÍA ANTON, J.: “ob. cit.”, p. 557; VEAS ARTESEROS, F.A. y JIMÉNEZ ALCÁZAR, J.F.: “ob. cit.”, p. 232-233.

151 ZURARA, Gomes Eanes de: Crónica do Conde D. Pedro de Meneses, Ediçao e Estudo Maria Teresa Brocardo, Lisboa, 1997, p. 531.

${ }^{152}$ El 1 de julio de 1476 recibía 200 maravedíes del concejo gienense por haber traído desde Huelma dos cautivos cristianos que faltaban. El 4 de noviembre volvió con dos muchachos que habían sido secuestrados once días antes, ocho mantas y dos calderos. El concejo acuerda mandar una carta al alguacil mayor de Granada dándole las gracias. A.M.J. Actas Capitulares 1476, f.153v. y 208 r. GARRIDO AGUILERA, J.C.: “ob. cit.", p. 169. 
lo qual, confiando en la linpieza del dicho ofiçio, el dicho Martín de Lara fue fiador de todo aquello quel dicho Hamete debe, en que monta çiertas contías de maravedíes e doblas, segund paresçe por la quenta que entre amos alhaqueques fecha es. E que agora, muy honrrado cauallero, quel dicho Hamete, no guardando la fieldad de su ofiçio, no quiere venir a esta çibdad a pagar e conplir todo aquello que es obligado (...) pues el dicho Hamete de vuestra parte e dese reyno es alhaqueque público e por tal nonbrado, de espeçial graçia vos pedimos luego le mandeis que venga a esta çibdad a conplir e pagar todo lo que así debe (...)".

A fines de diciembre seguía sin aparecer. Fue entonces cuando el contador Alfonso Díaz, que había estado en Granada resolviendo otras querellas, volvió diciendo que el alguacil mayor le había prometido que "pasada la Pascua venga aquí Martín de Lara e no le faltará cosa alguna de la justicia, e el Majo pagará"153.

El 20 de diciembre de 1480 los regidores de Jaén atienden las reclamaciones de Juan de Madrid y Martín de Lara sobre la deuda -60.000 maravedíes--que "Hamete el Majo" tenía contraída con ellos por determinadas transacciones de rescate. Esta reclamación hizo que el concejo autorizara a Juan de Madrid a entrar en tierra de moros a tomar prendas. El día 27 el susodicho volvió con un moro blanco de veinte años y anunció "que traerá otras cosas de otros moros que tomó"154.

Ese mismo día el concejo de Jaén escribía al alguacil mayor de Granada justificando la incursión hecha en territorio granadino:

“(...) Ya sabeis quantas veses vos avemos escripto sobre rason de la debda que está por las /quentas/ fechas que Hamete el Majo, vuestro alhaqueque público, debe y es obligado a dar e pagar a Martín de Lara e Juan de Madrid, nuestros alhaqueques, de los cativos e dineros que el dicho Hamete el Majo reçibió del dicho Martín de Lara segund por las quentas entre ellos fechas paresçio.

E por nuestras cartas vos requerimos e rogamos administrando justiçia fisiesedes pagar todos los dichos (en blanco) maravedíes al dicho Martin de Lara. Y por vos, muy honrado cavallero, nos fue respondido por vuestras cartas y sellos que el dicho Hamete el Majo venía a esta çibdad y pagaría la dicha debda al dicho Martín de Lara y por nos fue así rogado se sobreseyese y lo fiso. Y no vino ni pagó, y después por otra carta e cartas varias nos escrevistes que estava muy mal el dicho Hamete el Majo y que en mejorándose que estara bueno en quinse días vernía e pagaría al dicho Martín de Lara. Y después por otra vuestra carta nos enviastes rogar a terçero e quarto e quinto requerimiento nuestro que nos rogavades fisiesemos Martín de Lara que se sobreseyese fasta otros treinta días e que en este plaso que se vendían unas casas y heredades del dicho Hamete el Majo e que vendidas, dentro de los treinta días pagará al dicho Martín de Lara.

Y nos, muy honrrado cavallero, en el amor que vos tenemos, ovimos por bueno que se sobreseyese como lo queríades y en todo aquel tienpo el dicho Martín de Lara e sus fiadores estuvieron presos en la cárçel e vendidos sus bienes para pagar a quien él devía, y fasta agora, vos honrado cavallero alguna ves nos enbiais sobre algund vesino de ese reino por (...)a la vez les conplimos de justiçia y non consentimos que sean agraviados, y asi paresçe (muy) tenemos justa queja en no se guardar justiçia al dicho

153 CARRIAZO y ARROQUIA, J. de M.: “ob. cit.”, 40. Debe referirse a la Pascua de Ramadan.

${ }^{154}$ A.M.J. Actas Capitulares, 1480, f. 80 v. y 82 r. GARRIDO AGUILERA, J.C.: “ob. cit.”, p. 171. 
Martín de Lara, el qual a esta causa está perdido e pobre el dicho Martín de Lara y sus fiadores fasta tanto que por conplir de justiçia al dicho Martín de Lara y /ver nuestras cartas/ quedaron sin efeto y nuestro vesino quedó agraviado. A requerimiento suyo e de sus parientes e fiadores, nos mandamos faser la prenda en un moro de ese reino, blanco (...) acá está (...) mandar al dicho Hamete el Majo que luego venga a esta çibdad y pague los dichos maravedíes de la dicha debda al dicho Martín de Lara y luego vos enbiaremos el dicho moro como se troxo $(\ldots)^{155}$.

\subsection{EL RIESGO DE APOSTASÍA}

Hubo casos de conversión voluntaria a la otra fe. Gracias a un acta notarial cordobesa de 1470 sabemos de un joven de 18 años, que llevaban a Granada para ser canjeado por un cristiano. Antes de partir manifestó su deseo de recibir el bautismo, para lo cual estaba dispuesto, una vez en su tierra, a huir de ella y volver al país de los cristianos. Pide que su deseo conste por escrito con objeto de que, a la vuelta, sea acogido amigablemente por ellos y no se le someta a un nuevo cautiverio y, en consecuencia, a un nuevo y posible canje ${ }^{156}$.

Un tal "Elubrein", cautivo en Lorca, entrega a su hijo como rehén a fin de ir a Vera - su lugar de residencia - a reunir dinero. Al cabo de cierto tiempo vuelve por el muchacho, y descubre que se había convertido. Al enterarse su madre, lo reclama con insistencia. Puestas de acuerdo las justicias de Vera y Lorca, llevan al mozuelo a la Fuente de la Higuera, para que decida su destino. El muchacho no duda en renunciar a su antigua fe y, también a su familia, diciendo que su padre y su madre eran los que estaban en Lorca, a donde regresó. Se sabe de otro suceso similar acaecido en 1460, si bien esta vez el padre, al volver de Vera con el dinero, se convierte al cristianismo con su hijo, el rehén. Su madre lo reclama, es llevado a la Fuente de la Higuera, e insiste en reunirse con su padre ${ }^{157}$.

Eran los jóvenes, apresados en incursiones o llevados a territorio castellano en calidad de rehenes, quienes se mostraban más propensos a apostatar, a menudo voluntariamente. La pesquisa sobre los "elches" de Granada llevada a cabo en 1499-1500 por iniciativa del cardenal Cisneros, nos depara algún testimonio interesante sobre el particular. Juan de Granada, antes "Alhaje Abrahem”, declara:

"El era moro de nasçimiento, e de hedad de veynte años poco más o menos se tornó christiano en Éçija en una iglesia que está en la plaça e se puso nonbre Juan, esto puede aver sesenta años poco más o menos, y que después de tornado christiano pudo aver quarenta años poco más o menos se vino a esta çibdad de Granada e se tornó moro e ha bivido como moro fasta agora"158.

Describe con naturalidad el cambio de religión. Según el derecho islámico, los prisioneros en tierra de infieles estaban obligados a observar la ley musulmana mientras pudieran y, asimismo, debían observar la ley del territorio si no entraba en conflicto

\footnotetext{
155 A.M.J. Actas Capitulares 1480, f. 83v.-84r. GARRIDO AGUILERA, J.C.: “ob. cit.”, p. 171.

156 CABRERA MUÑOZ, E.: “ob. cit.”, 146.

157 GARCÍA ANTÓN, J.: “ob. cit.”, I, p. 557-558.

158 LADERO QUESADA, M.A.: “ob. cit.”, p. 305.
} 
con la propia. Pero los cautivos no incurrían en pena alguna si se veían forzados a cometer actos contra la ley coránica, incluyendo la renuncia a su propio credo. Tratándose de mujeres sometidas a "apuros, fatigas, penalidades físicas", inicialmente debían "aguantar, sufrir con paciencia, la persecución". Pero si eran amenazadas de muerte, se consideraba lícito que se sometieran a las demandas del enemigo, aunque de mala gana ${ }^{159}$.

\section{PARA CONCLUIR}

El canciller Pero López de Ayala señala, en relación con en el pogrom de 1391, que los revoltosos no se atrevieron a hacer lo mismo con los musulmanes "por quanto ovieron reçelo que los christianos que estavan cativos en Granada e en allen mar fuesen muertos"160.

Los castellanos eran conscientes de que los abusos cometidos sobre los cautivos de la parte contraria podían tener repercusiones negativas en los propios. En 1380 Juan I ordenó a los arrendadores y recaudadores de la alcabala en el partido de Murcia que dejaran de cobrar el impuesto sobre la cuantía por la que se rescataban los cautivos musulmanes, y que devolvieran lo ya cobrado. De lo contrario perjudicaría a los cristianos presos en tierra de moros "porque semejante les farían a ellos quando se oviesen a remedir e quitar"161.

Del lado granadino, preocupaciones similares explican el contenido de una fetua, ácrona, de un muftí sin identificar. Varios juristas malagueños le habían planteado el caso de un paisano suyo que poseía un esclavo cristiano a punto de alcanzar la pubertad. Un alfaqueque venido de Castilla rescata a este esclavo, que inmediatamente abraza el Islam. El alfaqueque solicita tomar posesión del esclavo o ser reembolsado. Pero la petición es rechazada porque el esclavo es musulmán y el amo no quiere devolver el dinero del rescate. A los juristas malagueños les preocupa que el alfaqueque se marche sin dinero ni cautivo, porque podría interpretarse como una violación de la tregua que le permitió venir a Málaga para cumplir su misión. Temen que esta actitud dañe a los cautivos granadinos que están en manos de sus adversarios, haciendo más difícil su liberación. El muftí responde que es preciso anular el rescate del cautivo y restituir su precio al alfaqueque, quedando el esclavo en poder de su amo. Esto no ha de afectar a la liberación de los musulmanes que se encuentran presos al otro lado de la frontera, dada la avidez que los cristianos sienten por el dinero ${ }^{162}$.

159 KHADDURI, Majid: War and Peace in the Law of Islam, Baltimore, 1955, p. 174.

${ }^{160}$ Cf. LÓPEZ de AYALA, Pero: Coronica de Enrique III, p. 24.

${ }^{161}$ La carta real, fechada en Soria a 22 de septiembre de 1380, destaca lo insólito del caso: el pago de la alcabala afectaba sólo a "las cosas que conpraren e vendieren".SUÁREZ FERNÁNDEZ, L.: ob. cit., doc. 158 , p. 200-201.

${ }^{162}$ HASNAOUI, M. : “ob. cit.”, p.555-556; LAGARDÈRE,Vincent : ob. cit., p. 72, doc. 291. 